Article

\title{
Renewable/Fuel Cell Hybrid Power System Operation Using Two Search Controllers of the Optimal Power Needed on the DC Bus
}

\author{
Nicu Bizon ${ }^{1,2,3, *(\mathbb{D}}$, Mircea Raceanu ${ }^{2,3, *(\mathbb{D})}$, Emmanouel Koudoumas ${ }^{4}$, Adriana Marinoiu ${ }^{2}$, \\ Emmanuel Karapidakis ${ }^{4}$ and Elena Carcadea ${ }^{2}$ (D) \\ 1 Faculty of Electronics, Communication and Computers, University of Pitesti, 110040 Pitesti, Romania \\ 2 ICSI Energy, National Research and Development Institute for Cryogenic and Isotopic Technologies, \\ 240050 Ramnicu Valcea, Romania; adriana.marinoiu@icsi.ro (A.M.); elena.carcadea@icsi.ro (E.C.) \\ 3 Faculty of Electronics, Telecommunications and Information Technology, Doctoral School, \\ University Politehnica of Bucharest, Splaiul Independentei Street no. 313, 060042 Bucharest, Romania \\ 4 Department of Electrical and Computer Engineering, Hellenic Mediterranean University, \\ GR-71004 Heraklion, Greece; koudoumas@hmu.gr (E.K.); karapidakis@hmu.gr (E.K.) \\ * Correspondence: nicu.bizon@upit.ro (N.B.); mircea.raceanu@icsi.ro (M.R.)
}

Received: 9 October 2020; Accepted: 16 November 2020; Published: 21 November 2020

\begin{abstract}
In this paper, the optimal and safe operation of a hybrid power system based on a fuel cell system and renewable energy sources is analyzed. The needed DC power resulting from the power flow balance on the DC bus is ensured by the FC system via the air regulator or the fuel regulator controlled by the power-tracking control reference or both regulators using a switched mode of the above-mentioned reference. The optimal operation of a fuel cell system is ensured by a search for the maximum of multicriteria-based optimization functions focused on fuel economy under perturbation, such as variable renewable energy and dynamic load on the DC bus. Two search controllers based on the global extremum seeking scheme are involved in this search via the remaining fueling regulator and the boost DC-DC converter. Thus, the fuel economy strategies based on the control of the air regulator and the fuel regulator, respectively, on the control of both fueling regulators are analyzed in this study. The fuel savings compared to fuel consumed using the static feed-forward control are $6.63 \%, 4.36 \%$ and $13.72 \%$, respectively, under dynamic load but without renewable power. With renewable power, the needed fuel cell power on the DC bus is lower, so the fuel cell system operates more efficiently. These percentages are increased to $7.28 \%, 4.94 \%$ and $14.97 \%$.
\end{abstract}

Keywords: proton-exchange membrane fuel cell; fuel-saving; optimization; safe and healthy strategy; electrical energy efficiency

\section{Introduction}

With the rapid increase in electricity consumption and the depletion of fossil fuel reserves, additional demands have emerged in national electricity generation networks. To eliminate this disadvantage, the use of alternative energy sources that are sustainable and environmentally friendly is considered [1]. Currently, the most important sources of renewable energy are based on energy captured from the sun, wind and water, considered to be the most promising renewable energy technologies. However, the energy produced from renewable energy sources (RES) has an intermittent nature largely due to climatic conditions, and therefore, it is not a continuous source of electricity $[2,3]$. Nevertheless, if an extra surplus of electricity appears, to avoid any problems in managing this intermittent energy, it can be consumed by an electrolyzer to produce hydrogen, which can be further converted into electricity through a fuel cell when there is a need for surplus energy or renewable 
energy is no longer available [4]. The proton exchange membrane fuel cell (PEMFC) can be used to manage the electrical load curve of the final consumers, offering in this way a proper option of balancing the frequency of the AC grid [5,6].

PEMFCs are devices that convert the chemical energy of hydrogen directly into electricity. This type of conversion is similar to the phenomenon that occurs in electrochemical batteries. The difference is that PEMFC is permanently supplied from the outside with fuels (hydrogen and oxygen) to generate electricity without interruption [7]. Normally, PEMFC is not capable of reversing the electrochemical process, as their basic function being to generate electrical power. There are special fuel cells that allow reversible operation. However, these are an exception [8,9]. The PEMFC transient response is strongly affected by the rate of the electrochemical reaction, especially from the cathode. Therefore, PEMFC is not the most appropriate choice in a stand-alone configuration, as it is not able to provide the power needed for fast load power transitions [10].

During applications on a real vehicle, the PEMFC stack is exposed mainly to four dynamic conditions, which have a significant impact on the durability and efficiency of the fuel cells: sudden load change (reactant starvation phenomenon and poor water management lead to the membrane drying and consequently to the loss of power of the PEMFC) [11-13], start-stop cycles [14-16] (lead to corrosion of the carbon support leading to platinum loss, irreversible damage), idle cycle [17-19] (the voltage at the cell level is in the range of $0.9 \mathrm{~V}$ and open-circuit voltage and may cause membrane dehydration and performance loss) and high power [19,20] (PEMFC efficiency is low, below $0.6 \mathrm{~V}$ voltage the components of the stack are rapidly degraded).

The performance of PEMFCs used in the automotive sector is strongly dependent on their lifetime, with an impact on their commercialization. If the commercial requirement was established at $5000 \mathrm{~h}$, in practice, it can only reach 2500-3000 $\mathrm{h}$ for automotive applications [21]. During automotive operation, the stoichiometry, temperature, humidity and voltage are strongly influenced by the electric current. Consequently, the Nafion membrane is subjected to the cyclic stress resulting from the repeated swelling and shrinkage of the membrane due to water sorption and desorption. For these reasons, the local pinholes can develop, which accelerates the rapid degradation of the membrane. The appearance of pinholes leads to an increase in the crossover of the reactants, and implicitly, the electrical contacts between MEA, GDL and bipolar plates are affected. Consequently, this leads to decreased open-circuit voltage (OCV), higher ohmic losses and, therefore, to a decreased fuel cell performance [22-24]. In addition, PEMFC degradation has been further investigated in many experimental works by finding novel solutions of platinum catalyst hybridization with other metals/nonmetals, taking into account certain drastic conditions for accelerated PEMFC degradation [25-30]. The results so far indicate that the decrease in performance during the frequent start-stop cycles was very severe [31]. Therefore, it is important to pay greater attention to developing system strategies to improve the sustainability of PEMFC, especially in start/stop cycles [32,33].

The ESS power needs to sustain the load for almost $2 \mathrm{~s}$ in order to increase the FC power from $10 \%$ to $90 \%$ and moreover to prevent the decrease in the FC lifetime [34]. Therefore, the PEMFC stack is hybridized with other power sources to suppress transient load regimes. Hybrid power systems (HPS) have a much better dynamic response while also contributing to the increased lifetime of PEMFC. Generally, PEMFC systems are used as a primary energy source, and peak power demand is usually provided from auxiliary energy storage sources (ESS). By coupling a high-energy-density source (PEMFC) and a high-power density source (an ultracapacitor (UC) is used in this study), the performance of hybrid power sources can be optimized [35].

Fuel cell technology is still very expensive; therefore, new solutions are being sought to reduce costs and, in particular, different control algorithms to increase PEMFC performance, taking into account the four dynamic operating conditions. Optimal control of the oxygen excess ratio (OER) must be implemented to avoid starvation based on the current produced by the stack. A reference value of the OER ratio is calculated through different control methods. In [36], a fuzzy control scheme successfully calculates airflow for different stack currents and temperatures. In [37], an adaptive 
controller is used to adjust the air temperature at the cathode inlet to avoid dehydration and flooding while preventing starvation. Repeatedly starting and stopping a fuel cell during a driving cycle is a crucial operating sequence for MEA aging and which shortens the lifetime of the PEMFC. Eliminating this disadvantage can be solved quickly if the open-circuit voltage (OCV) of the PEMFC stack is brought to zero volts after the stack stops working. This is done using a shunt $[38,39]$ or through limited voltage control [19,40-42]. In order to have the maximum FC efficiency and implicitly a low fuel consumption, the maximum efficiency point (MEP) on the efficiency curve of the PEMFC stack must be followed (usually, the current density is around $0.4 \mathrm{~A} / \mathrm{cm}^{2}$ ). When the fuel cell must operate at maximum power, the maximum power point (MEP) on the power curve must be followed (usually, the current density is around $1 \mathrm{~A} / \mathrm{cm}^{2}$ ). MPP and MEP are usually sought by implementing a tracker that controls the hydrogen and air regulator so that the efficiency or power of the PEMFC is maximized. Different approaches are used to control MPPT/MPET, which can be divided into perturb and observe algorithms [43-45], fuzzy logic control [46-48], sliding mode control [49-51], and extremum seeking control [52-55].

Rechargeable batteries (batteries) allow the conversion of both electrochemical energy into electricity and also electricity into electrochemical energy. The storage capacity and power at the battery terminals is dependent on their type. Depending on the application, the correct type of batteries will be chosen [56]. UCs are devices that store electricity in the form of an electric field. The operation of a UC versus a conventional capacitor differs by the transfer of ions into the dielectric material, which leads to a higher value of the specific capacitance. Even so, the energy density of a UC is much lower than for a battery; however, the power density of the UC is significantly higher [57]. By combining batteries, UCs and PEMFCs, an HPS with improved power flexibility can be achieved $[35,58]$. UCs can reduce transient regimes due to low impedance [53,59].

The interconnection topologies of hybrid power sources (HPS) and energy management strategies (EMS) are closely related to the specificity of the application. Meeting the energy consumption profile is a key objective that must be respected. For example, automotive applications have a random load profile due to accelerations/decelerations, where the speed of change of current and power is extremely high and sudden [60]. For example, the current consumed by the engine of a vehicle, in the acceleration phase, can reach up to $100 \mathrm{~A} / \mathrm{s}$ [61]. In these specific applications, mainly, the current is limited by the reaction rate of the PEMFC; therefore, the transient response of the PEMFC is limited to such power demands [62]. Therefore, for automotive applications, UCs offer higher power density than batteries and are therefore usually preferred. Currently, the academic and industrial research focuses in particular on applications in the stationary and automotive fields, delimiting the aspects related to hydrogen storage [63]. The requirement to meet the power demand in stationary applications is not as pressing as in the automotive field. The interconnection topologies of HPS and EMS are designed to reduce costs, dimensions and hydrogen consumption. Academic and industrial research is currently focused on innovative algorithms and topologies to meet all conflicting requirements. Passive hybrid topologies are not justified to be implemented in high power applications due to their poor performance in terms of the lifecycle and reduced fuel consumption [64]. Therefore, only active hybrid topologies will be analyzed below. In the literature, several hybrid architectures are proposed. The innovative solutions of interconnection topologies are divided into three main classes: multilevel [65], common bus [55] and multi-input topologies [66]. Existing solutions differ mainly in the flexibility of design, complexity and cost reduction. Batteries and UCs are typically used as active storage elements [67].

In this paper, three fuel economy strategies based on the control of the air regulator and the fuel regulator, respectively, on the control of both fueling regulators were analyzed from the point of view of consumed hydrogen by an FC HPS without and with power from renewable energy sources (RES). The static feed-forward (sFF) control is used as a benchmark strategy under the same dynamic profiles of the load demand and renewable power (see Figure 1). All the strategies used in this work are safe, healthy and efficient strategies. The safety is given by the oxygen excess ratio (OER). The healthy is for the battery, which operates in sustained charging mode by using power-tracking control (PTC) 
for the FC system. The efficiency of RES FC HPS is measured using performance indicators, such as the electrical energy efficiency and hydrogen consumption of the FC system. The optimization loops use two global extremum seeking (GES) schemes operating at different frequencies to maximize the multimodal optimization function that combines the performance indicators.
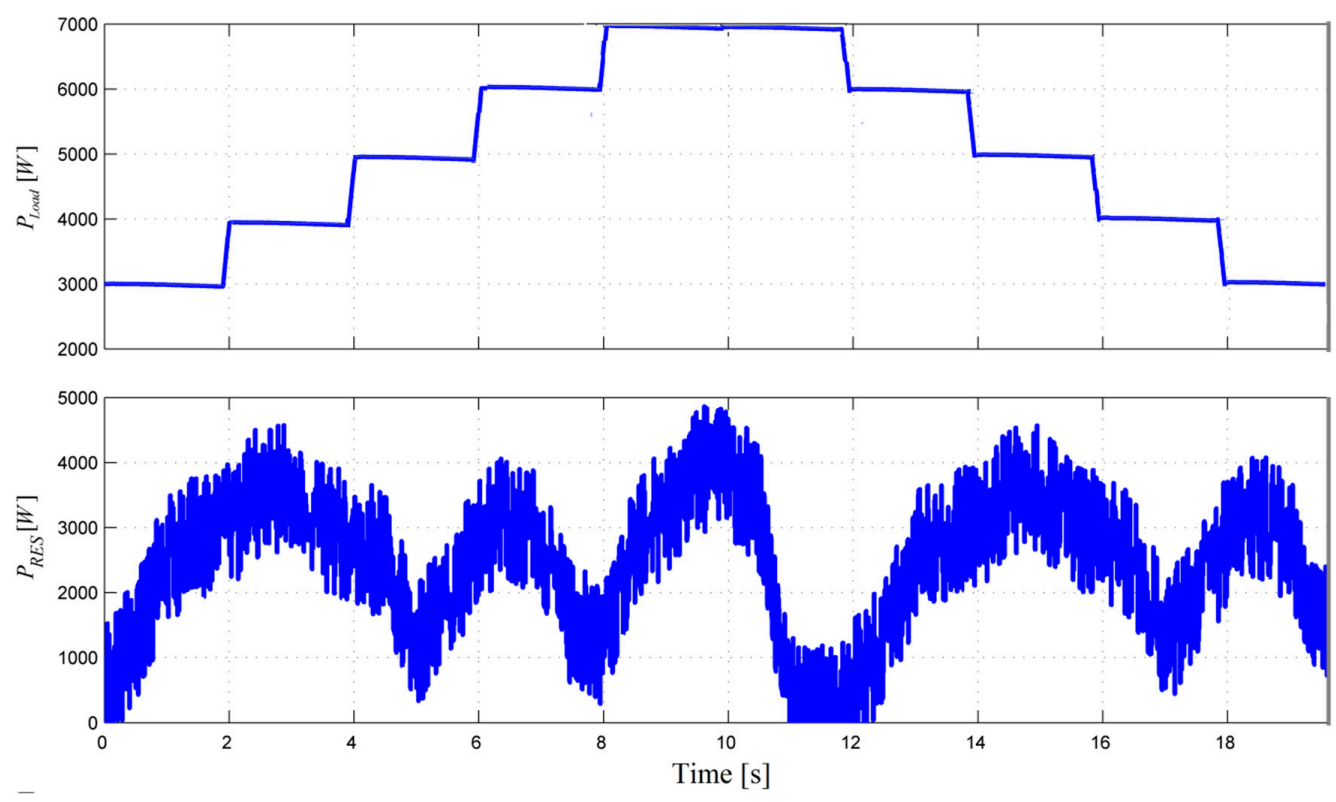

Figure 1. Dynamic profiles of load demand and renewable energy used in simulations.

Following this analysis, the structure of the paper is as follows: The first section details the model of FC HPS without and with RES power and PTC-based optimization strategies. The second and third sections show and analyze comparatively the results obtained using PTC-based optimization strategies for the same operating conditions of the FC HPS. The last section concludes the paper.

\section{Materials and Methods}

\subsection{The Test Conditions}

To fairly compare the sFF strategy with fuel economy strategies based on the control of the air regulator and the fuel regulator, respectively on the control of both fueling regulators (which will be called below as Air-PTC-2GES, Fuel-PTC-2GES and Air/Fuel-PTC-2GES), the same operating conditions must be used for RES FC HPS. Thus, the dynamic profiles of the load demand and renewable power are presented in Figure 1.

The load profile $\left(P_{\text {Load }}\right)$ is of the scale type, with levels of $1 \mathrm{~kW}$, up and down, changed every $2 \mathrm{~s}$, as it is shown in the first plot of Figure 1 . The renewable energy profile $\left(P_{R E S}\right)$ with an average value of about $2.2 \mathrm{~kW}$ is based on a variable profile that is spread by adding a random power with a peak of $1 \mathrm{~kW}$ (see the second plot of Figure 1).

\subsection{The Architecture of the Hybrid Power System}

The main blocks of the RES FC HPS and its energy management unit (EMU) are shown in Figure 2.

A hybrid power source (HPS), fed by renewable energy sources (RESs) and fuel cell (FC) sources, with an energy storage systems (ESS - batteries and ultracapacitors stacks), equivalent load (AC and DC loads), DC-DC boost converter for FC, bidirectional buck-boost converter for battery and EMU (containing two GES controllers, the GES controller 1 and the GES controller 2, which are referred to below as GES1 and GES2) is developed. A $6 \mathrm{~kW} \mathrm{FC} \mathrm{system} \mathrm{with} \mathrm{the} \mathrm{slope} \mathrm{limits} \mathrm{of} 100 \mathrm{~A} \mathrm{~s}^{-1}$ for the fuel regulators and $0.2 \mathrm{~s}$ time constant was employed as a backup energy source. The battery/ultracapacitor 
hybrid ESS operates as an auxiliary source for supplying the power deficit considering the dynamic power balance strategy. The power flow balance is sustained by $100 \mathrm{Ah}$ battery/100 $\mathrm{F}$ ultracapacitors energy storage system (ESS) using a semi-active ESS topology having the battery on $200 \mathrm{~V}$ DC bus and the ultracapacitors via a bidirectional DC-DC buck-boost converter.

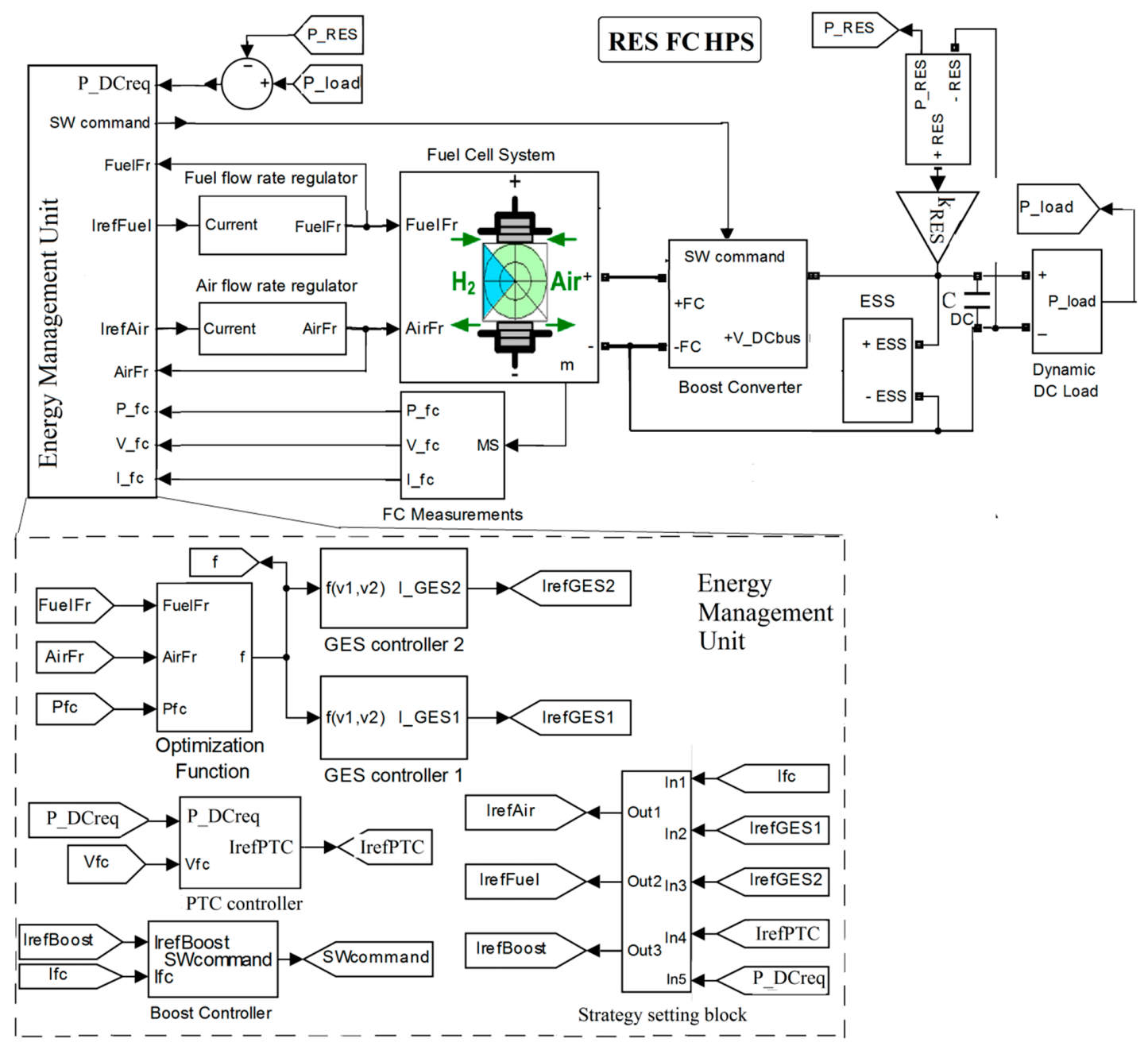

Figure 2. Renewable energy sources (RES) fuel cell (FC) hybrid power source (HPS) and energy management unit (EMU).

\subsection{Design of the Power-Tracking Control (PTC)}

The power flow balance on the DC bus is given by (1):

$$
C_{D C} u_{D C} d u_{D C} / d t=p_{D C}+p_{R E S}+p_{E S S}-p_{L o a d}
$$

where $C_{D C}$ is the $10,000 \mu \mathrm{F}$ capacitor that filters the DC voltage $u_{D C}, p_{D C}=\eta_{b o o s t} p_{F C \text { net }}$ is the power generated by the FC system on the DC bus, $p_{F C n e t}$ is the FC net power, $\eta_{\text {boost }}$ is the efficiency of the DC-DC boost converter, $p_{R E S}$ is RES power, $p_{E S S}$ is ESS power exchanged to compensate the power flow balance (1) and $p_{\text {Load }}$ is load demand.

If $p_{D C}=\eta_{\text {boost }} p_{F C \text { net }}=p_{D C \text { req }} \cong p_{\text {Load }}-p_{R E S}$, then, considering the mean value of (1), will result (2):

$$
P_{E S S(M V)} \cong 0 \Rightarrow P_{\text {Batt }(M V)} \cong 0
$$

where subscript MV represents the mean value of the power during a load cycle. Thus, the battery will be operated in charge-sustained mode, which increases its lifetime and reduces the maintenance 
costs $[68,69]$. The ultracapacitors will dynamically sustain the power flow balance (1) through control of the bidirectional DC-DC buck-boost converter based on the DC voltage regulation loop.

Thus, considering MV of (1) and (2), FC net power requested on the DC bus is given by (3):

$$
P_{F C n e t} \cong P_{D C r e q(M V)} / \eta_{\text {boost }}=\left(P_{\text {Load }(M V)}-P_{R E S(M V)}\right) / \eta_{\text {boost }}
$$

The FC power that is generated on the DC bus is the FC net power $\left(P_{F C n e t}\right)$ :

$$
V_{F C} \cdot I_{F C}=P_{F C n e t} \cong P_{F C}-P_{c m},
$$

where $P_{F C}$ and $P_{c m}$ are the FC stack power and the power losses of the air compressor, and $V_{F C}$ and $I_{F C}$ are the voltage and the current of the FC stack.

The compressor power losses can be modeled by (5) in series with a 2nd order dynamic system having $100 \mathrm{~Hz}$ natural frequency and 0.7 damping ratio [70,71]:

$$
P_{c m}=I_{c m} \cdot V_{c m}=\left(a_{2} \cdot A_{i r F r}^{2}+a_{1} \cdot A i r F r+a_{0}\right) \cdot\left(b_{1} \cdot I_{F C}+b_{0}\right)
$$

where $a_{0}=0.6, a_{1}=0.04, a_{2}=-0.00003231, b_{0}=0.9987$ and $b_{1}=46.02$.

Considering (3) and (4), the power-tracking control (PTC) will be implemented using the $I_{\text {ref }(P T C)}$ reference given by (6):

$$
I_{\text {ref }(P T C)}=\left(P_{\text {Load }(M V)}-P_{R E S(M V)}\right) /\left(V_{F C(M V)} \cdot \eta_{\text {boost }}\right) \cong I_{F C}
$$

\subsection{The Fuel Economy Strategies}

The fuel economy strategy is based on the optimization function (9) and the global extremum seeking (GES) controller that search and track in real time the optimum of (7):

$$
f\left(x, \text { AirFr }, \text { FuelFr }, P_{\text {Load }}, P_{R E S}\right)=0.5 \cdot P_{F C n e t}+k_{f u e l} \cdot \text { Fuel }_{\text {eff }}
$$

where Fuel $_{\text {eff }} \cong P_{F C n e t} /$ FuelFr measures the fuel consumption efficiency, $x$ represents the vector of FC state variables $[52,55,72-75]$, and GES variables are the airflow rate (AirFr) and the fuel flow rate (FuelFr) given by (8) and (9) [72,76]:

The fueling flow rates for fuel (FuelFr) and air (AirFr) are as follows:

$$
\begin{gathered}
\text { AirFr }=\frac{60000 \cdot R \cdot(273+\theta) \cdot N_{C} \cdot I_{r e f(A i r)}}{4 F \cdot\left(101325 \cdot P_{f(O 2)}\right) \cdot\left(U_{f(O 2)} / 100\right) \cdot\left(y_{O 2} / 100\right)} \\
F u e l F r=\frac{60000 \cdot R \cdot(273+\theta) \cdot N_{C} \cdot I_{r e f(F u e l)}}{2 F \cdot\left(101325 \cdot P_{f(H 2)}\right) \cdot\left(U_{f(H 2)} / 100\right) \cdot\left(x_{H 2} / 100\right)}
\end{gathered}
$$

and $N_{C}, \theta, U_{f(\mathrm{H} 2)}, U_{f(\mathrm{O} 2)}, P_{f(\mathrm{H} 2)}, P_{f(\mathrm{O} 2)}, x_{\mathrm{H} 2}, y_{\mathrm{O} 2}$ are default parameters $[73,77]$.

It is worth mentioning that $k_{\text {fuel }}$ can be set at zero to maximize $P_{F C n e t}[43]$ or at $25[\mathrm{lpm} / \mathrm{W}]$ (the optimal value of this parameter was obtained by a sensitivity analysis) to reduce the hydrogen consumption, total fuel consumption defined by $\mathrm{Fuel}_{T}=\int F u e l F r(t) d t[78,79]$. The last setting is used in this study.

Two GES controllers will generate the references $I_{r e f(G E S 1)}$ and $I_{r e f(G E S 2)}$ by tracking the maximum of the optimization function (7) under disturbances, such as load and renewable power, with the profiles shown in Figure 1. PTC-2GES based fuel economy strategies called Air-PTC-2GES, Fuel-PTC-2GES and Air/Fuel-PTC-2GES can be implemented through the strategy settings block as it is presented in 
Figure 3, which will select the input references $I_{r e f(P T C)}, I_{r e f(G E S 1)}$ and $I_{r e f(G E S 2)}$ to the output references $I_{r e f(B o o s t)}, I_{r e f(A i r)}$ or $I_{r e f(F u e l)}$ as determined by (10a), (10b) and (10c), respectively:

$$
\begin{aligned}
& I_{\text {ref(Fuel })}=I_{F C}+I_{\text {ref(GES2) }}, I_{\text {ref }(\text { Air })}=I_{\text {ref(PTC) })}, I_{\text {ref(boost })}=I_{\text {ref(GES1) }} \\
& I_{r e f(A i r)}=I_{F C}+I_{r e f(G E S 2)}, I_{r e f(F u e l)}=I_{r e f(P T C)}, I_{r e f(b o o s t)}=I_{r e f(G E S 1)} \\
& I_{\text {ref(Fuel })}=\left\{\begin{array}{c}
I_{\text {ref(PTC) }}, \text { if } P_{D C r e q} \leq P_{r e f} \\
I_{F C}+I_{r e f(G E S 2)}, \text { if } P_{D C r e q}>P_{r e f}
\end{array}\right. \\
& I_{\text {ref }(\text { Air })}=\left\{\begin{array}{c}
I_{F C}+I_{r e f(G E S 2)}, \text { if } P_{D C r e q} \leq P_{r e f} \\
I_{r e f(P T C)}, \text { if } P_{D C r e q}>P_{r e f}
\end{array}\right. \\
& I_{r e f(b o o s t)}=I_{r e f(G E S 1)}
\end{aligned}
$$

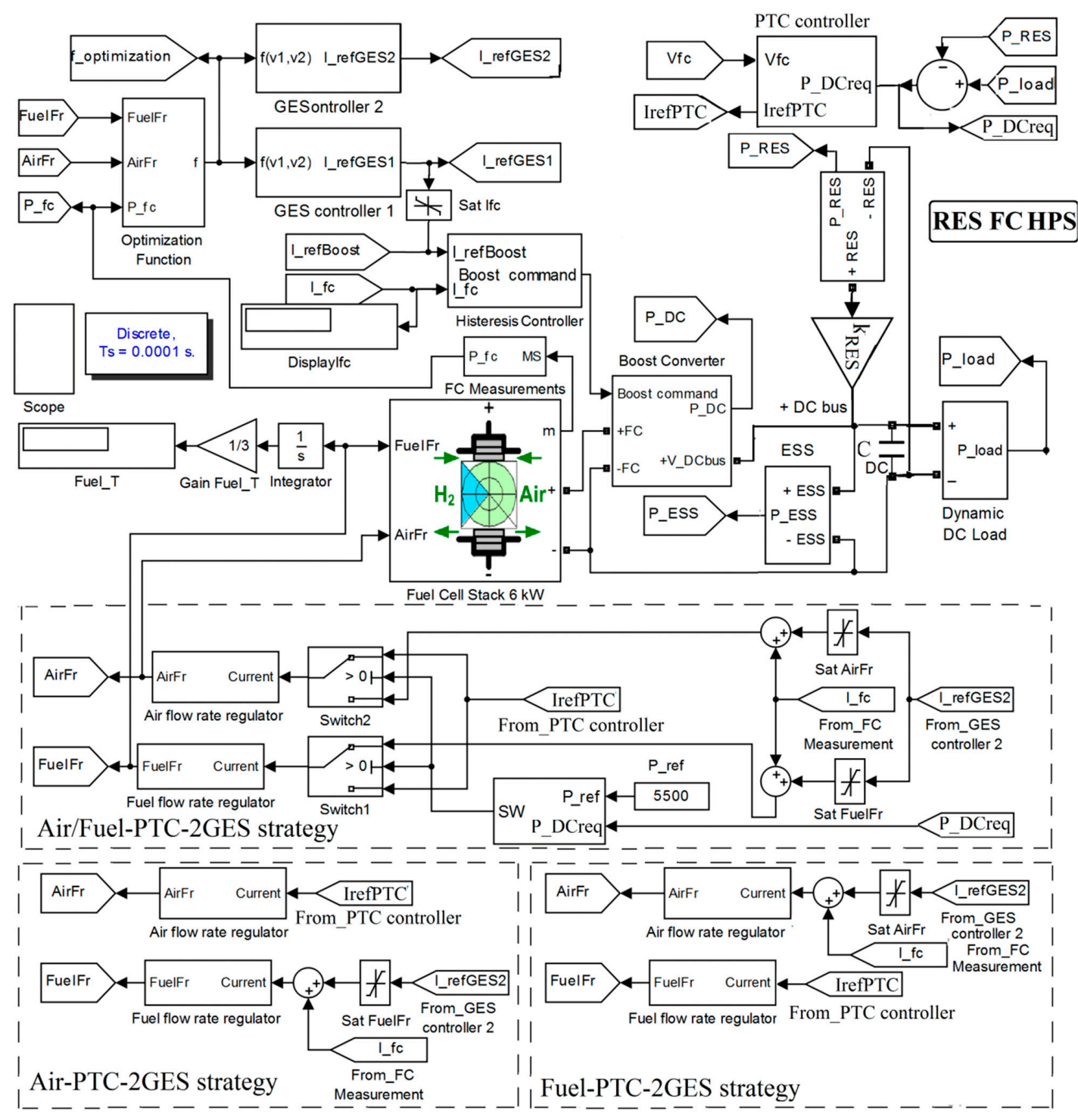

Figure 3. The RES FC HPS using the strategies Air/Fuel-power-tracking control (PTC) with two global extremum seeking (GES) controllers: Air-PTC-2GES and Fuel-PTC-2GES.

The $P_{\text {ref }}$ threshold of $5.5 \mathrm{~kW}$ is used in the Air/Fuel-PTC-2GES strategy: $I_{\text {ref }(P T C)}$ reference is switched to the air and fuel regulator for $P_{D C r e q}=P_{\text {Load }}-P_{R E S}>0$ lower and higher than the 
threshold $P_{r e f}$. In the strategies Air-PTC-2GES and Fuel-PTC-2GES, $I_{r e f(P T C)}$ reference is the input of the air regulator or the fuel regulator, respectively.

If $P_{D C \text { req }}=P_{\text {Load }}-P_{R E S}<0$, then $P_{R E S}-P_{\text {Load }}>0$, so an electrolyzed can be supplied with this excess power to produce hydrogen.

The diagram of RES FC HPS using the strategies Air-PTC-2GES, Fuel-PTC-2GES and Air/Fuel-PTC-2GES is shown in Figure 3. Parameter $k_{\text {RES }}$ sets the operation of HPS without and with renewable power (for example, $k_{R E S}=0 \Rightarrow P_{R E S}=0$ ).

The operation of the RES FC HPS using the aforementioned strategies is compared with the static feed-forward (sFF) strategy using the setting given by (11) [74]:

$$
I_{r e f(F u e l)}=I_{F C}, I_{r e f(A i r)}=I_{F C}, I_{r e f(b o o s t)}=I_{r e f(P F C)}
$$

\subsection{The Global Extremum Seeking (GES) Controller}

Both GES controllers have the scheme shown in Figure 4. The signal processing relationships 12a-f are determined by the blocks presented in Figure 4:

$$
\begin{gathered}
y=f(\text { AirFr, FuelFr })=0.5 \cdot P_{F C n e t}+k_{f u e l} \cdot \text { Fuel }_{e f f}, y_{N}=k_{N y} \cdot y \\
\dot{y}_{f}=-\omega_{h} \cdot y_{f}+\omega_{h} \cdot y_{N}, y_{H P F}=y_{N}-y_{f}, \dot{y}_{B P F}=-\omega_{l} \cdot y_{B P F}+\omega_{l} \cdot y_{H P F} \\
\omega_{h}=b_{h} \omega, \omega_{l}=b_{l} \omega, s_{d}=\sin (\omega t), \omega=2 \pi f_{d}, \\
y_{D M}=y_{H P F} \cdot s_{d}, \dot{y}_{\text {Gradient }}=y_{D M}, p_{1}=k_{1} \cdot y_{\text {Gradient }} \\
y_{M}=\left|\frac{1}{T_{d}} \cdot \int y_{B P F} d t\right|, p_{2}=k_{2} \cdot y_{M} \cdot s_{d} \\
I_{r e f(G E S)}=k_{N p} \cdot\left(p_{1}+p_{2}\right)
\end{gathered}
$$

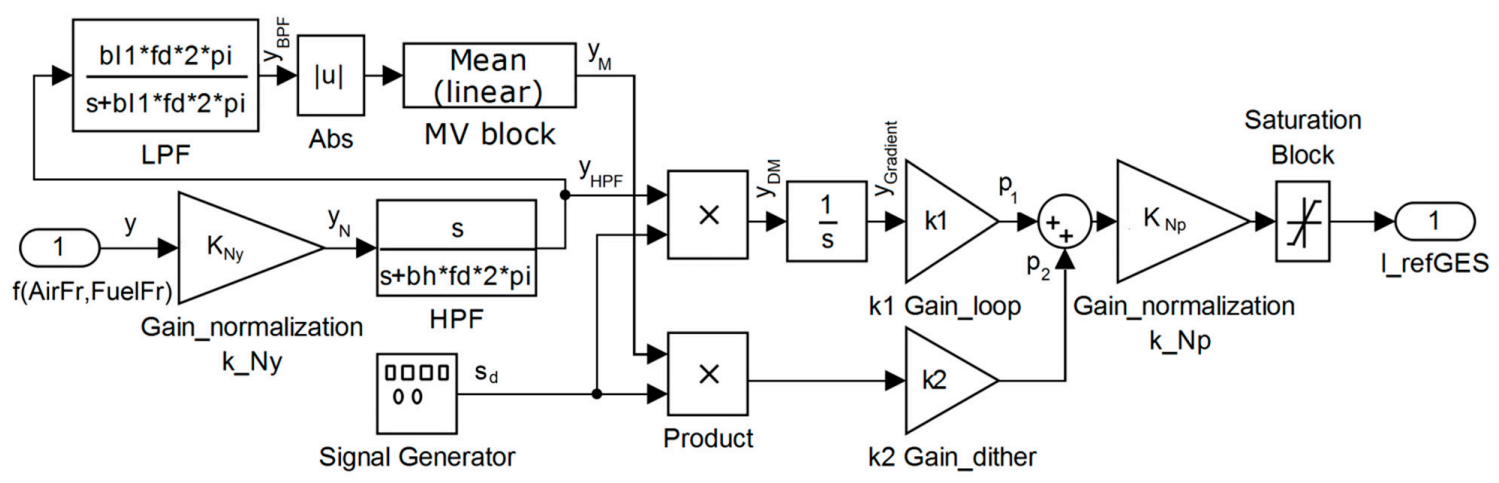

Figure 4. GES controller.

The design and analysis of GHG control are detailed in the references [43,76-78]. In this paper, is made only a brief presentation of the variables and parameters used. The input of the GES controller, which is the optimization function $\mathrm{f}$, is normalized using $\mathrm{k}_{\mathrm{Ny}}=1 / 1000$. The first harmonic of the $y_{N}$ signal is demodulated with different sinusoidal dithers, $s_{d 1}=\sin \left(\omega_{1} t\right)$ and $s_{d 2}=\sin \left(\omega_{2} t\right)$, and integrated to obtain the search gradient $\left(y_{\text {Gradient }}\right)$, where $\omega=2 \pi f_{d}$, and $f_{d 1}=50 \mathrm{~Hz}$ and $f_{d 2}=100 \mathrm{~Hz}$ for the controllers GES1 and GES2, respectively. The yM signal, which modulates the dithers, is an approximation of the first harmonic of the $\mathrm{y}_{\mathrm{N}}$ signal (which is obtained using a band-pass filter and a mean value (MV) block to further smooth the signal). The cut-off frequencies of the band-pass filter are $\omega_{l}=b_{l} \omega$ and $\omega_{h}=b_{h} \omega$, where $\beta_{l}=1.5$ and $\beta_{h}=0.1$. The search and location signals $\left(p_{1}\right.$ and $\left.p_{2}\right)$ are tuned using $k_{1}$ and $k_{2}$ to speed up tracking of the optimum. In this study, $k_{1}=1$ and $k_{2}=2$ for both GES controllers. The signals $p_{1}$ and $p_{2}$ are summed and normalized using $k_{\mathrm{Np}}=20$. The limits of the 
saturation block are defined specifically for an FC system. Note the very good tracking accuracy of 99.9\% [73] and negligible ripple of FC power during stationary regimes [72].

\subsection{The Performance and Health Indicators}

The oxygen excess ratio (OER) given by (13) is a health indicator of the safe functioning of the FC system [79]:

$$
O E R=\frac{c_{3} \cdot I_{F C}^{3}+c_{2} \cdot I_{F C}^{2}+c_{1} \cdot I_{F C}+c_{0}}{d_{1} \cdot I_{F C}+d_{0}}
$$

where:

$$
c_{0}=402.6, c_{1}=8.476 \cdot 10^{-5}[1 / A], c_{2}=-0.81252\left[1 / A^{2}\right], c_{3}=0.02673\left[1 / A^{3}\right], d_{0}=0.997 \text { and }
$$
$d_{1}=61.38$.

OER can be controlled [70,79], but in this paper, OER is only monitored to see if the analyzed strategies are safe and healthy for the FC system.

The performance indicators usually used for the FC system are the total fuel consumption $\left(\mathrm{Fuel}_{T}\right)$, the fuel consumption efficiency (the Fuel eff $\cong P_{F C n e t} / F u e l F r$ ) and the electrical efficiency of the FC system $\left(\eta_{s y s}=P_{F C n e t} / P_{F C}\right)$.

\section{Results}

The hydrogen consumption is measured in liters [1] and computed using (14):

$$
\mathrm{Fuel}_{T}=\int_{0}^{t} \operatorname{Fuel} \operatorname{Fr}(\tau) d \tau
$$

If the hydrogen consumption is measured in liters per minute [lpm], then a gain of $1 / 3(=20 \mathrm{~s} / 60 \mathrm{~s})$ is necessary to be used because the load cycle used has 20 s, not one minute (see the Gain Fuel_T and Fuel_T display in Figure 4).

Furthermore, note the use in the simulation of $100 \mathrm{~A} / \mathrm{s}$ slope for the fueling regulators of $6 \mathrm{~kW}$ FC system, time constants of $0.2 \mathrm{~s}$ and $20 \mathrm{~s}$ for FC system and $100 \mathrm{Ah}$ battery, respectively, and hysteresis of $0.1 \mathrm{~A}$ and $1 \mathrm{~V}$ of the controllers used for the boost DC-DC converter and the buck-boost DC-DC bidirectional converter.

The performance of the analyzed strategies, Air/Fuel-PTC-2GES, Air-PTC-2GES and Fuel-PTC-2GES, will be highlighted compared to the reference standard strategy based on SFF control for HPS with and without the support of renewable energy.

\subsection{Hydrogen Consumption}

3.1.1. Behavior of FC HPS Operating without Power from Renewable Energy Sources $\left(k_{R E S}=0\right)$

The operation of the FC HPS using the strategies sFF, Air-PTC-2GES, Fuel-PTC-2GES and Air/Fuel-PTC-2GES is presented in Figures 5-8, respectively, considering the load demand shown in the first plot of Figure 1.

The reference elements from the study (FC HPS operation) are presented schematically in Figures 5-8, in the form of plots (waveforms). The last three plots present the performance indicators $\left(\right.$ Fuel $_{T}$, Fuel $_{\text {eff }} \cong P_{F C \text { net }} /$ FuelFr and $\left.\eta_{\text {sys }}=P_{F C \text { net }} / P_{F C}\right)$, but for variable loads, hydrogen consumption is the only indicator that can give us a measure of performance. It can be easily seen that the hydrogen consumption (represented in Figure 5) changes partially, in the sense of improvement that depends on the control strategies used (see Figures 6-8). Therefore, the application of the proposed strategies can be beneficial in all cases. 


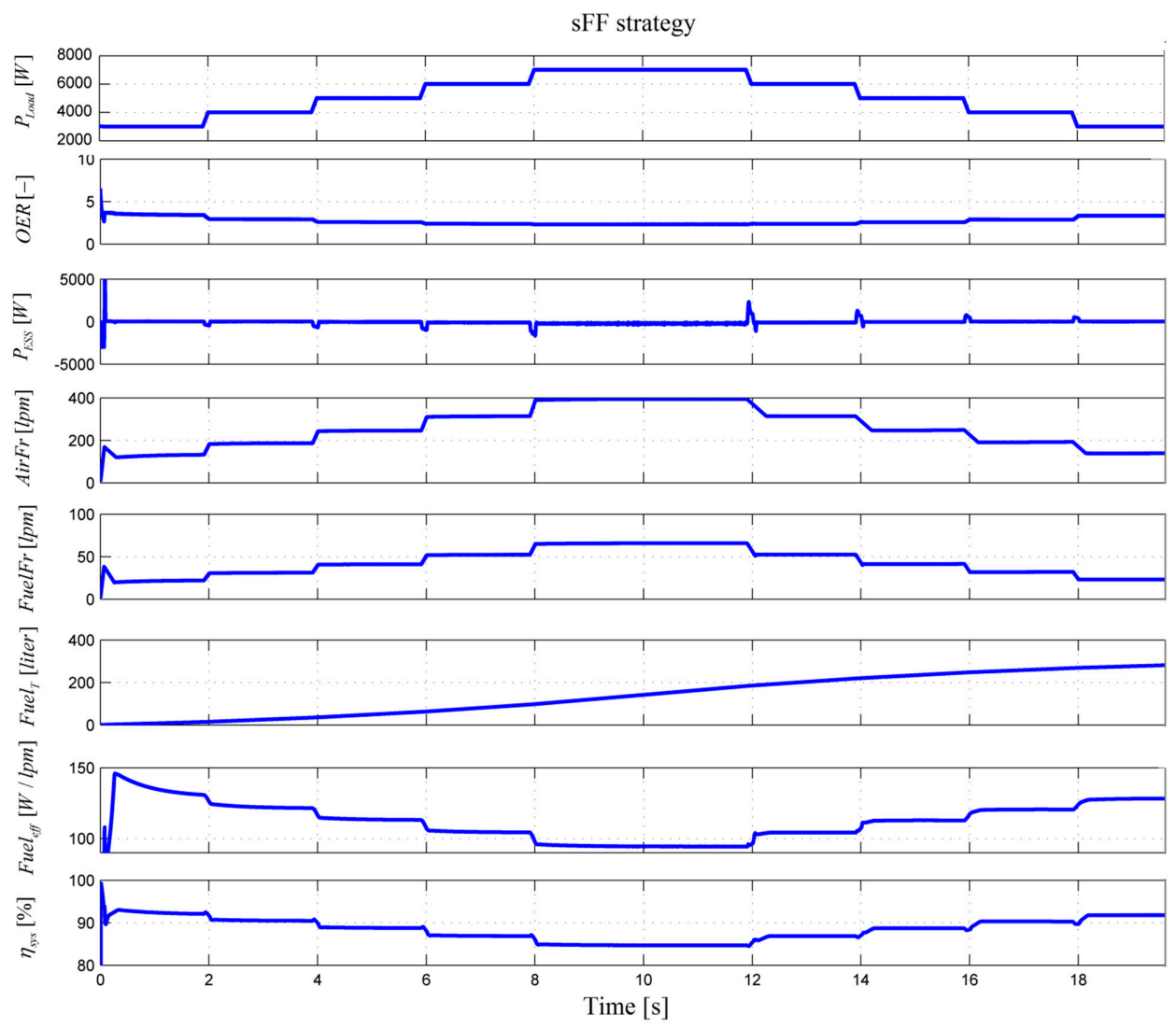

Figure 5. FC HPS operation using the static feed-forward (sFF) strategy.
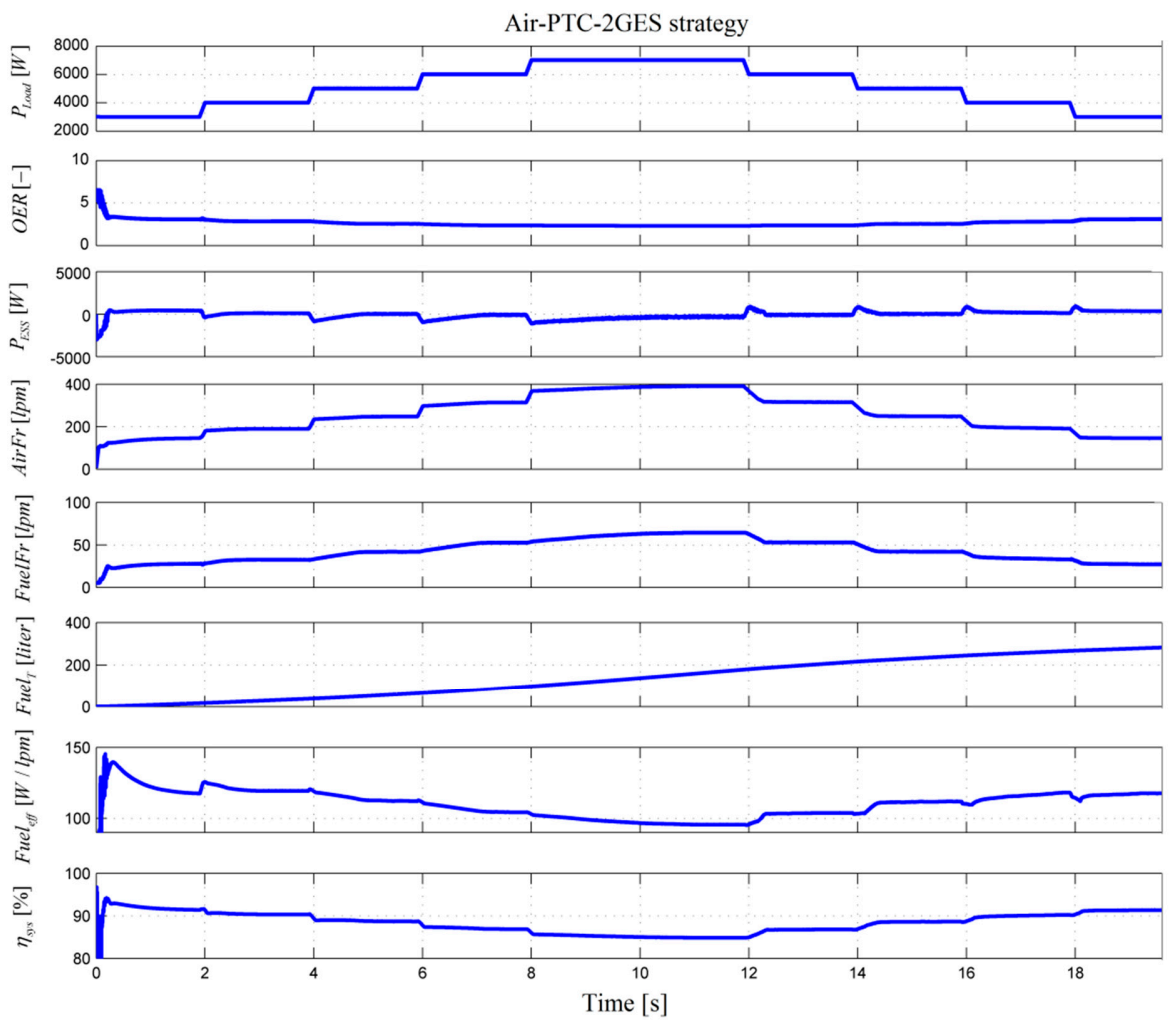

Figure 6. FC HPS operation using the Air-PTC-2GES strategy. 


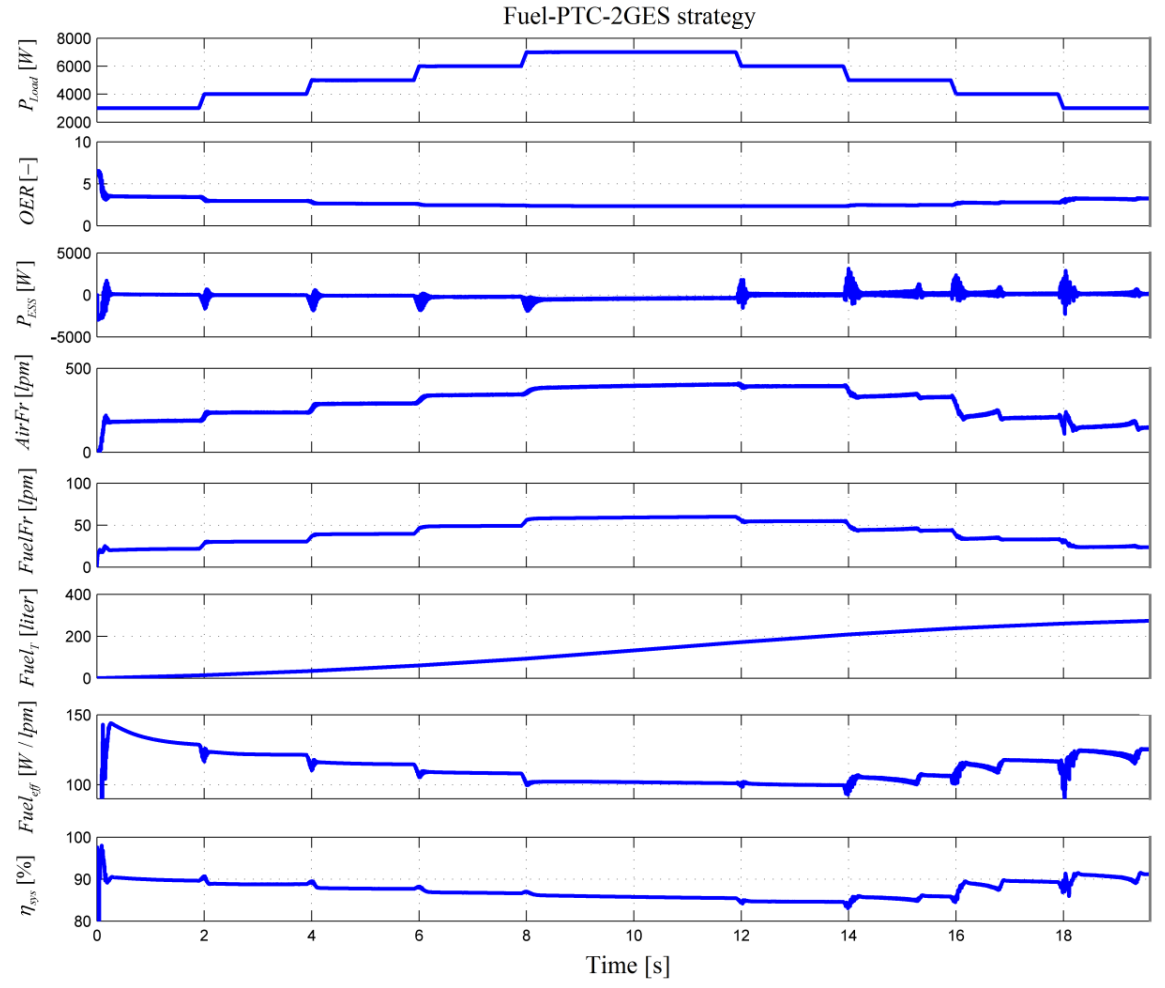

Figure 7. FC HPS operation using the Fuel-PTC-2GES strategy.

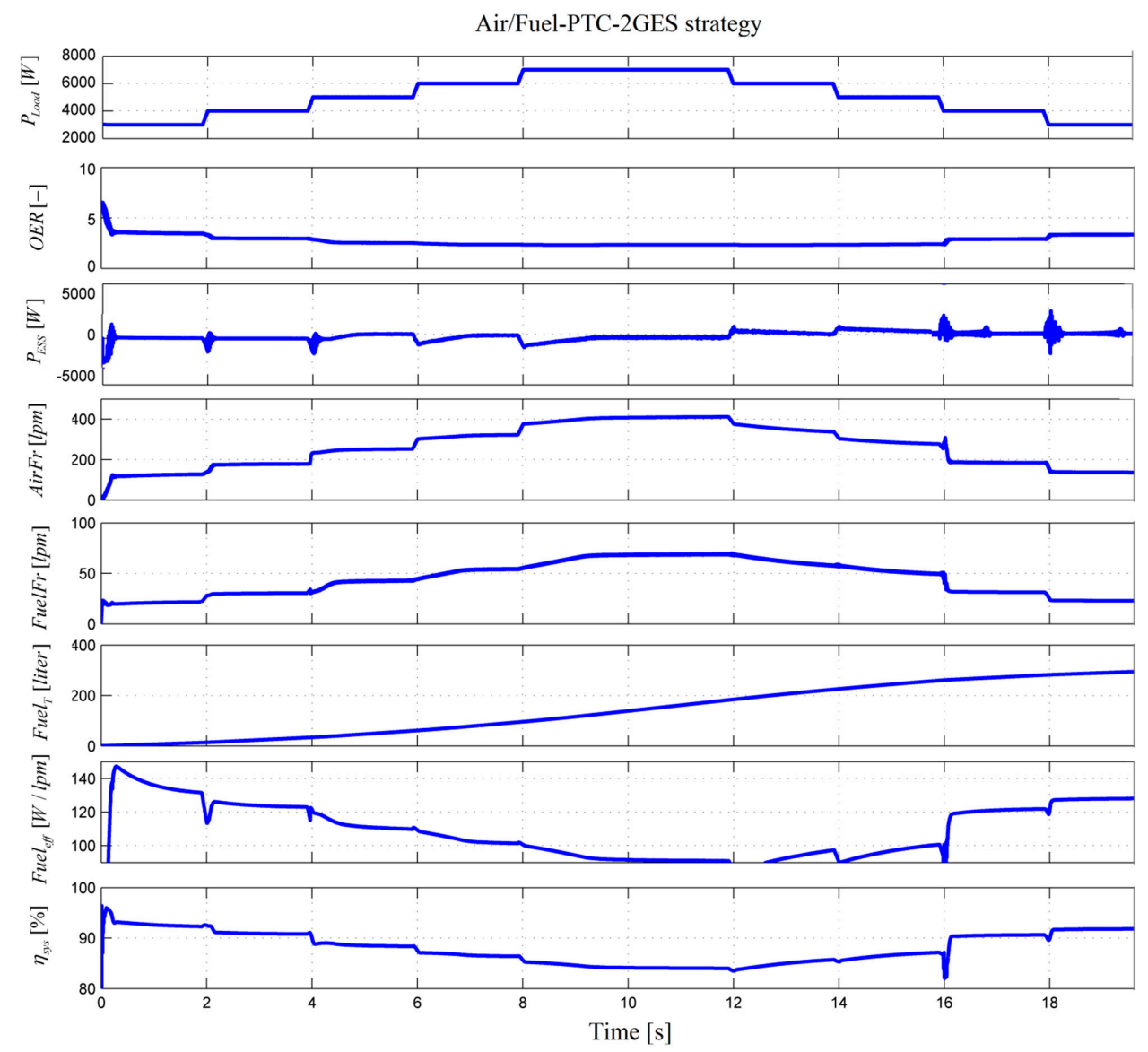

Figure 8. FC HPS operation using the Air/Fuel-PTC-2GES strategy. 
Hydrogen consumption for all strategies is registered in Table 1 . The hydrogen economy, compared to the sFF benchmark, is presented in Table 2 using (15) and $k_{R E S}=0$ :

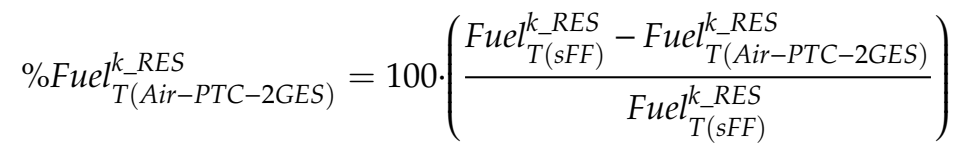

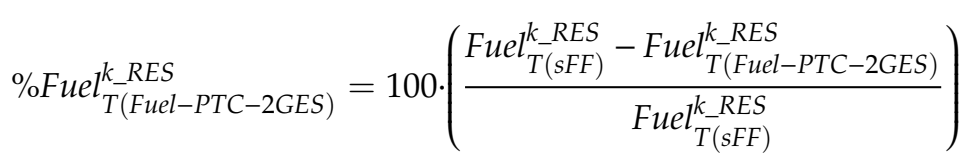

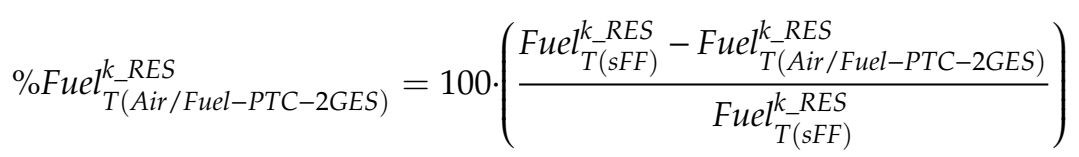

Table 1. Hydrogen consumption of the analyzed strategies and sFF benchmark for $k_{R E S}=0$.

\begin{tabular}{cccc}
\hline Fuel $_{T(\mathrm{sFF})}$ & Fuel $_{T(\text { Air-PTC-2GES })}$ & Fuel $_{T(\text { Fuel-PTC-2GES })}$ & Fuel $_{\text {T(Air/Fuel-PFC-2GES })}$ \\
\hline$[$ liters $]$ & {$[$ liters $]$} & {$[$ liters $]$} & [liters $]$ \\
\hline 286.5 & 267.5 & 274.0 & 247.2 \\
\hline
\end{tabular}

Table 2. Hydrogen economy of the analyzed strategies compared to the sFF benchmark.

\begin{tabular}{ccc}
\hline \%Fuel $_{T(\text { Air-PTC-2GES })}$ & \%Fuel $_{\text {T(Fuel-PTC-2GES })}$ & \%Fuel $_{T(\text { Air/Fuel-PTC-2GES })}$ \\
\hline$[\%]$ & {$[\%]$} & {$[\%]$} \\
\hline 6.63 & 4.36 & 13.72 \\
\hline
\end{tabular}

Variation of ESS power is around zero (see plot 3 in all Figures 5-8), confirming the operation of the battery in charge-sustaining mode.

The shape of the load demand is followed by both the AirFr and FuelFr in sFF strategy, by AirFr and FuelFr in the strategies Air-PTC-2GES and Fuel-PTC-2GES, respectively, and by FuelFr and then by AirFr in Air/Fuel- PTC-2GES strategy (see plots 4 and 5 in Figures 5-8, respectively).

Hydrogen consumption using the same strategies will be evaluated in the next section for FC HPS operating with power from renewable energy sources.

3.1.2. Behavior of FC HPS Operating with Power from Renewable Energy Sources $\left(k_{R E S} \neq 0\right)$

The operation of the RES FC HPS using the strategies sFF, Air-PTC-2GES, Fuel-PTC-2GES and Air/Fuel-PTC-2GES is presented in Figures 9-12, respectively, considering the RES power shown in the second plot of Figures 1 and $9-12$ as well).

The plots of Figures 9-12 represent the same waveforms as those in Figures 5-8, except for adding the waveform of RES power in the 2nd plot. Hence, the new structure of the plots is as follows: 1st plot and 2nd plot present the load demand and renewable power; 3rd plot-OER; 4th plot-ESS power; 5th and 6th plots-AirFr and FuelFr; 7th plot-Fuel $;$; 8th plot and 9th plot present the aforementioned performance indicators, Fuel $_{e f f}$ and $\eta_{s y s}$.

The fuel consumption under the analyzed strategies and sFF benchmark is registered in Table 3 for $k_{R E S}=1\left(P_{R E S}\right.$ is shown in Figure 1). The fuel economy of these strategies compared to the sFF benchmark is presented in Table 4 using (15).

If $P_{R E S}>P_{\text {Load }}$, then, the excess of power $\left(P_{R E S}-P_{\text {Load }}>0\right)$ can be used to produce hydrogen using an electrolyzer. In addition, the FC system must operate in standby mode (with FC power about $100 \mathrm{~W}$ ) to avoid the start/stop mode of operation. The values of Fuel $_{e f f}$ and $\eta_{s y s}$ are lower during FC standby mode (see the last two plots). 


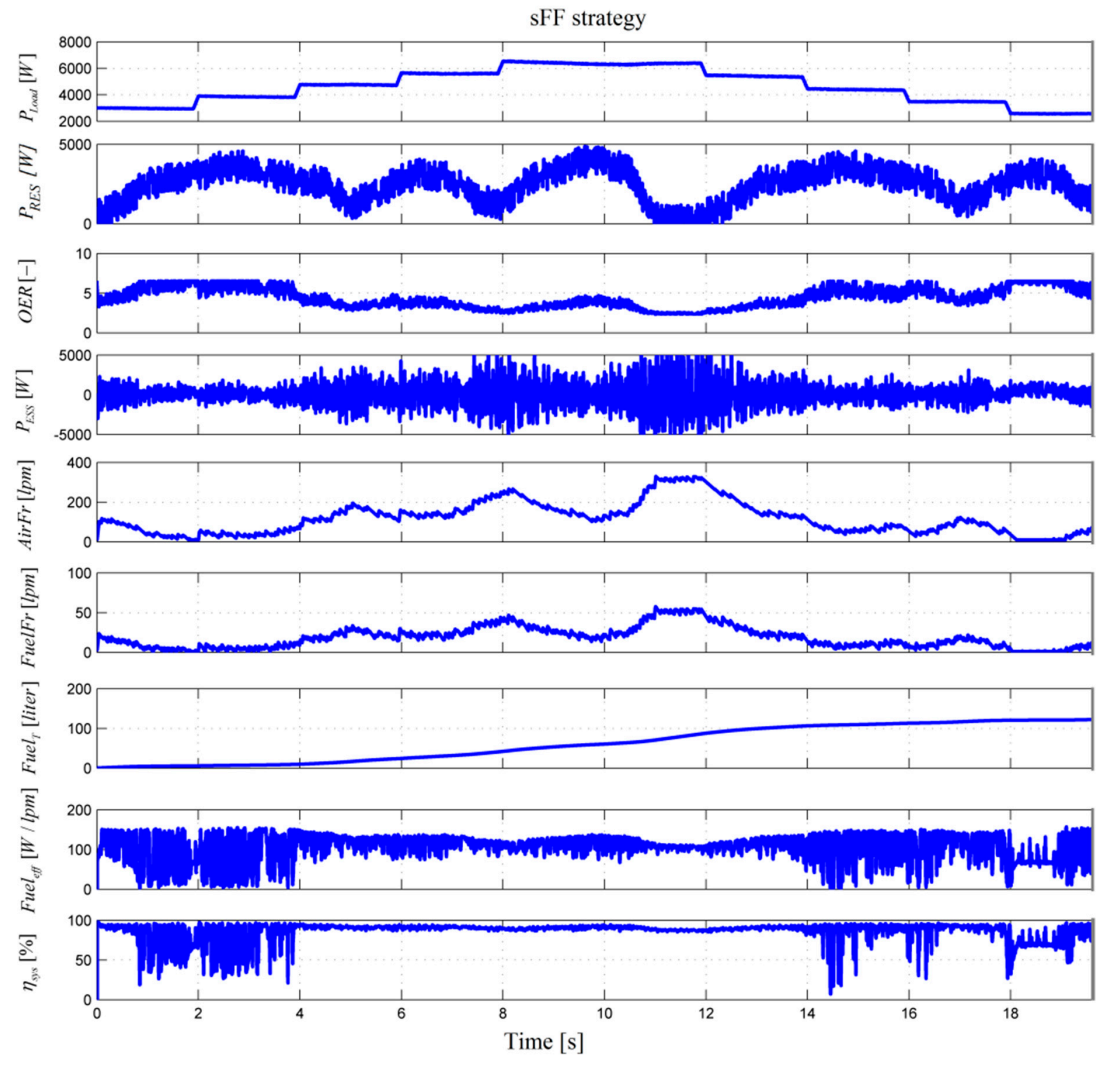

Figure 9. RES FC HPS operation using the sFF strategy.

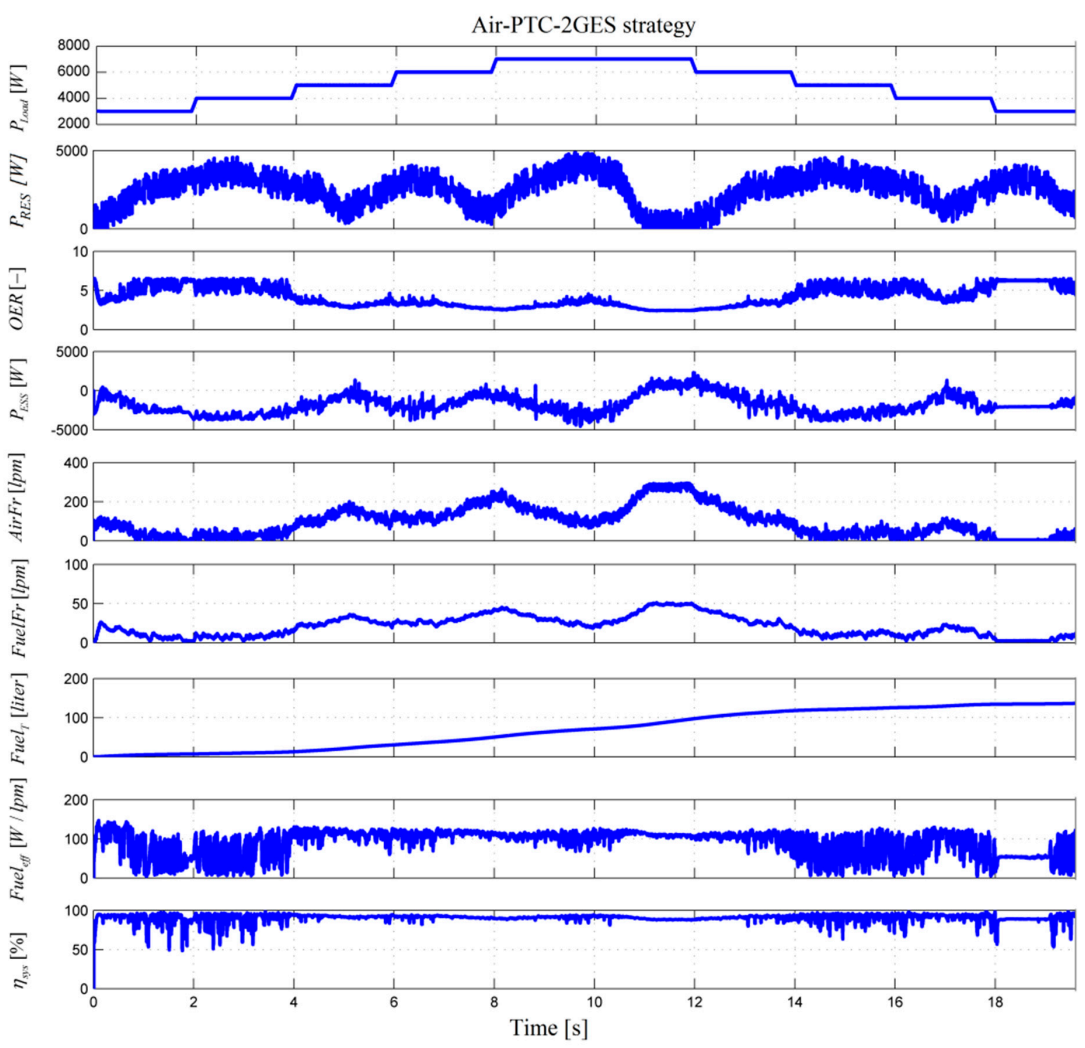

Figure 10. RES FC HPS operation using the Air-PTC-2GES strategy. 


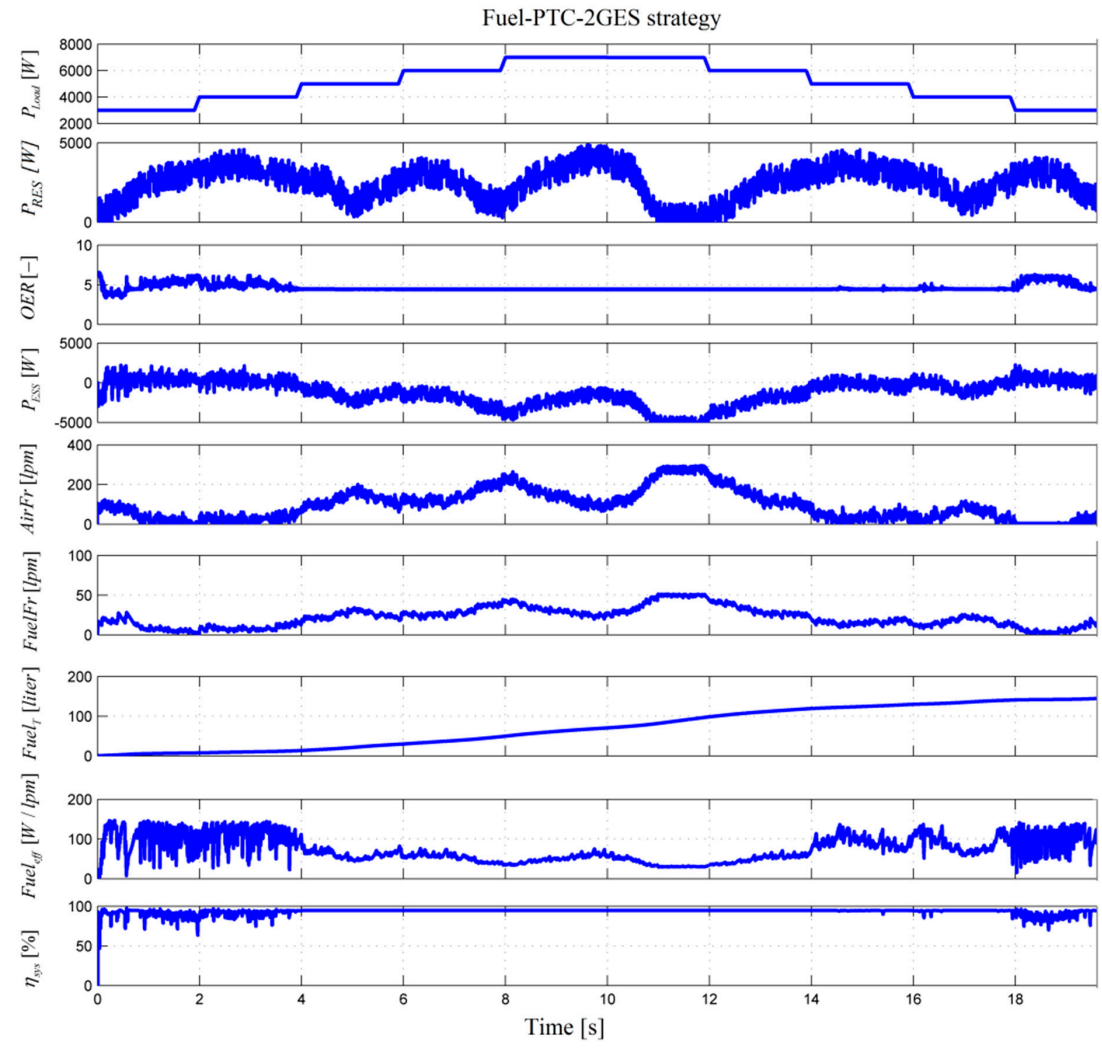

Figure 11. RES FC HPS operation using the Fuel-PTC-2GES strategy.

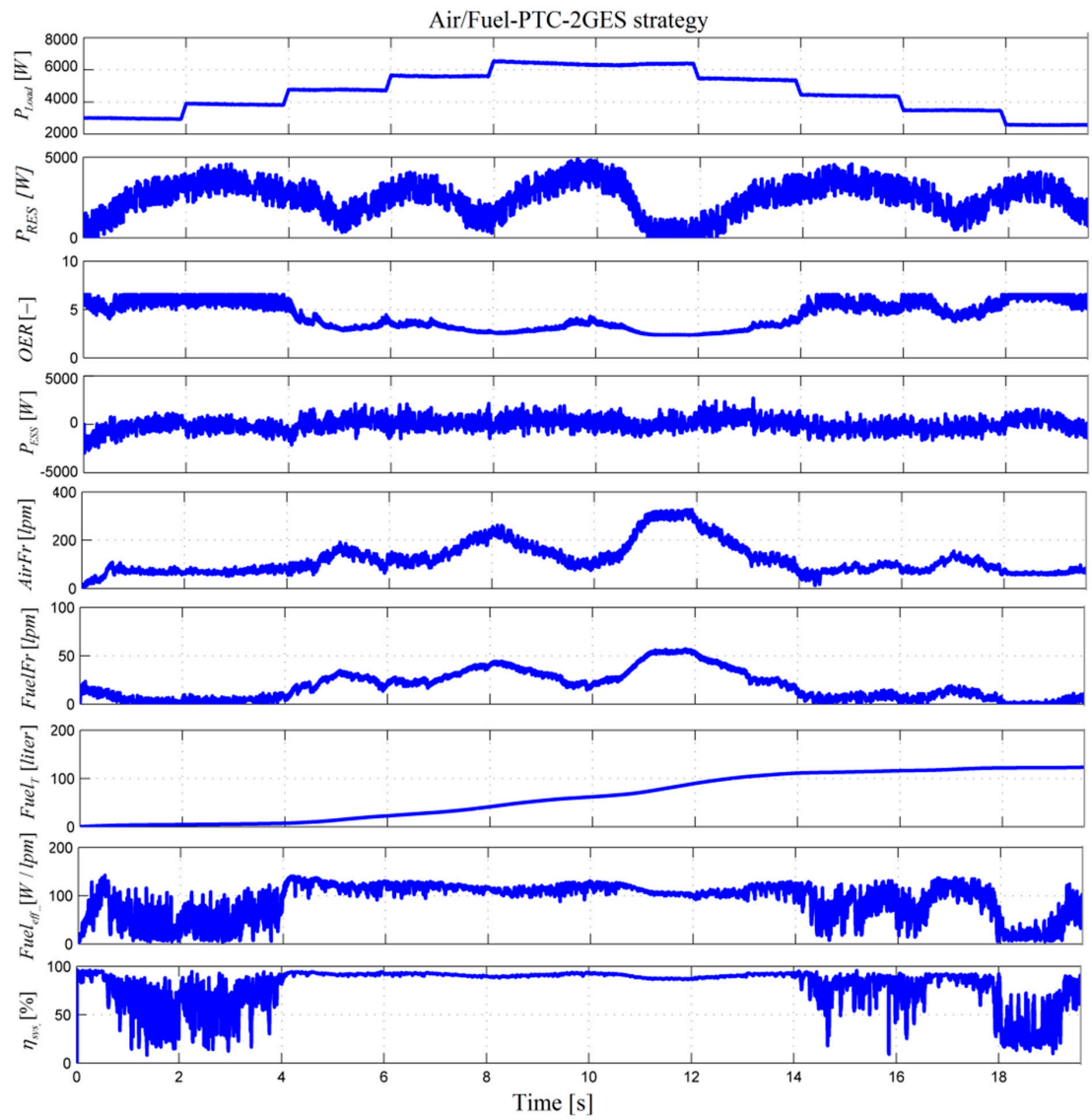

Figure 12. RES FC HPS operation using the Air/Fuel-PTC-2GES strategy. 
Table 3. Fuel consumption of the analyzed strategies and sFF benchmark for $k_{R E S}=1$.

\begin{tabular}{cccc}
\hline Fuel $_{T(\text { sFF })}^{\text {RES }}$ & Fuel $_{T(\text { Air-PTC-2GES })}^{\text {RES }}$ & Fuel $_{T(\text { Fuel-PTC-2GES })}^{\text {RES }}$ & Fuel $_{T(\text { Air/Fuel-PTC-2GES })}^{\text {RES }}$ \\
\hline$[$ liters $]$ & {$[$ liters $]$} & {$[$ liters $]$} & {$[$ liters $]$} \\
\hline 123.6 & 114.6 & 117.5 & 105.1 \\
\hline
\end{tabular}

Table 4. Fuel economy of the analyzed strategies compared to the sFF benchmark.

\begin{tabular}{ccc}
\hline$\%$ Fuel $_{T(\text { Air-PTC-2GES })}^{\text {RES }}$ & \%Fuel $_{T(\text { Fuel-PTC-2GES })}^{\text {RES }}$ & ${ }^{\text {FFuel }}{ }_{T(\text { Air/Fuel-PTC-2GES })}^{\text {RES }}$ \\
\hline$[\%]$ & {$[\%]$} & {$[\%]$} \\
\hline 7.28 & 4.94 & 14.97 \\
\hline
\end{tabular}

\subsection{FC Net Power and Electrical Efficiency}

\subsubsection{FC HPS}

The range of variation of FC electrical efficiency, $\eta_{s y s}=P_{F C n e t} / P_{F C}$, is from $84 \%$ to $93 \%$ (see plot 8 in Figures 5-8). The FC electrical efficiency decreases with the increase of the power density due to the high flow rates of the reactants. In practice, the flow rates of reactants with which FC is fed at the inlet are not fully consumed [75]. Figure 13 shows the fuel cell net power values taking into account the auxiliary power consumption of the BoP for all three control strategies compared to the sFF benchmark. It is observed that for lower load values, the FC system provides more power when the fuel/air regulators are controlled by the Air-PTC-2GES strategy and, while the loading power increases, the FC power decreases suddenly. This is explained by the fact that when the FC operates at low loads, it needs more airflow to increase the humidity of the membrane. Then, as the power load increases, the FC itself produces an increasing amount of water, which causes flooding in the canals and, therefore, a low efficiency. Increased values of the FC net power are obtained by the Air/Fuel-PTC-2GES strategy, especially for high loads. Although the value of $\mathrm{k}_{\text {fuel }}$ was set to 25 in the optimization function (7) to minimize fuel consumption, in Figure 13, it can be seen that the FC net power is higher than the value controlled by the sFF strategy. The Air/Fuel-PTC-2GES strategy uses a power threshold $(5.5 \mathrm{~kW})$ through which the Air-PTC-2GES and Fuel-PTC-2GES strategies are switched, benefiting from their advantages. Thus, for high load, the air regulator is regulated by the PTC controller, which controls the OER value below 2.5, from where the low energy consumption of the air compressor and an adequate membrane humidity level for high currents are obtained.

\subsubsection{RES FC HPS}

The variation of the FC net power supplied on the DC bus of RES FC HPS (see Figure 14) is from $100 \mathrm{~W}$ to $6 \mathrm{~kW}$, corresponding to the standby and nominal operating modes. Lower values of FC electrical efficiency, $\eta_{s y s}=P_{F C n e t} / P_{F C}$, appear for RES FC HPS during the standby operating mode (see plot 9 in Figures 9-13). During applications of an FC-HPS combined with RES, the FC system is exposed to many issues caused by rapid power transitions, which have a negative impact on the durability and efficiency of the FC system. One of the issues is the sudden change of load correlated with the intermittent power of RES, which can lead to the starvation phenomenon of reactants and poor water management inside the FC system, which leads to drying/flooding of the membranes and, consequently, to low efficiency. Another issue is the avoidance of the start-stop cycles of the FC system (where irreversible damage occurs due to the loss of platinum) and of the FC operation without load (which causes dehydration of the membrane). All these issues are successfully avoided by the Air/Fuel-PTC-2GES strategy, which limits the current produced by the FC system to $100 \mathrm{~A} / \mathrm{s}$ for the avoidance of the starvation phenomena; controls the OER rapport between 2.3 and 7 to adjust the optimal amount of water inside the FC (even if in certain situations this is done to the detriment of 
efficiency, especially at low loads) and sets the minimum operating the voltage threshold of the FC to avoid OCV and the excess power is converted into hydrogen by electrolysis.

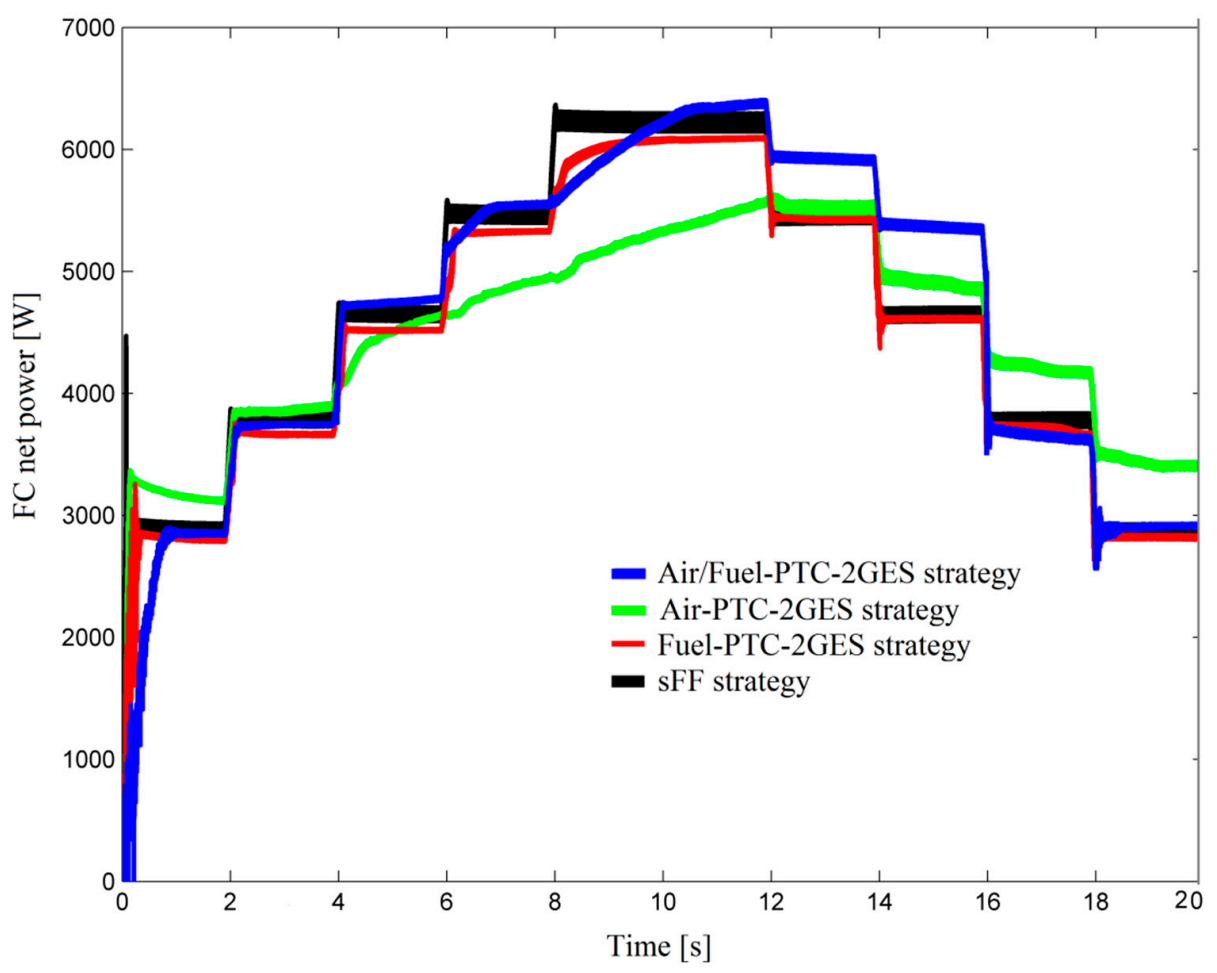

Figure 13. FC net power supplied on the DC bus of FC HPS.

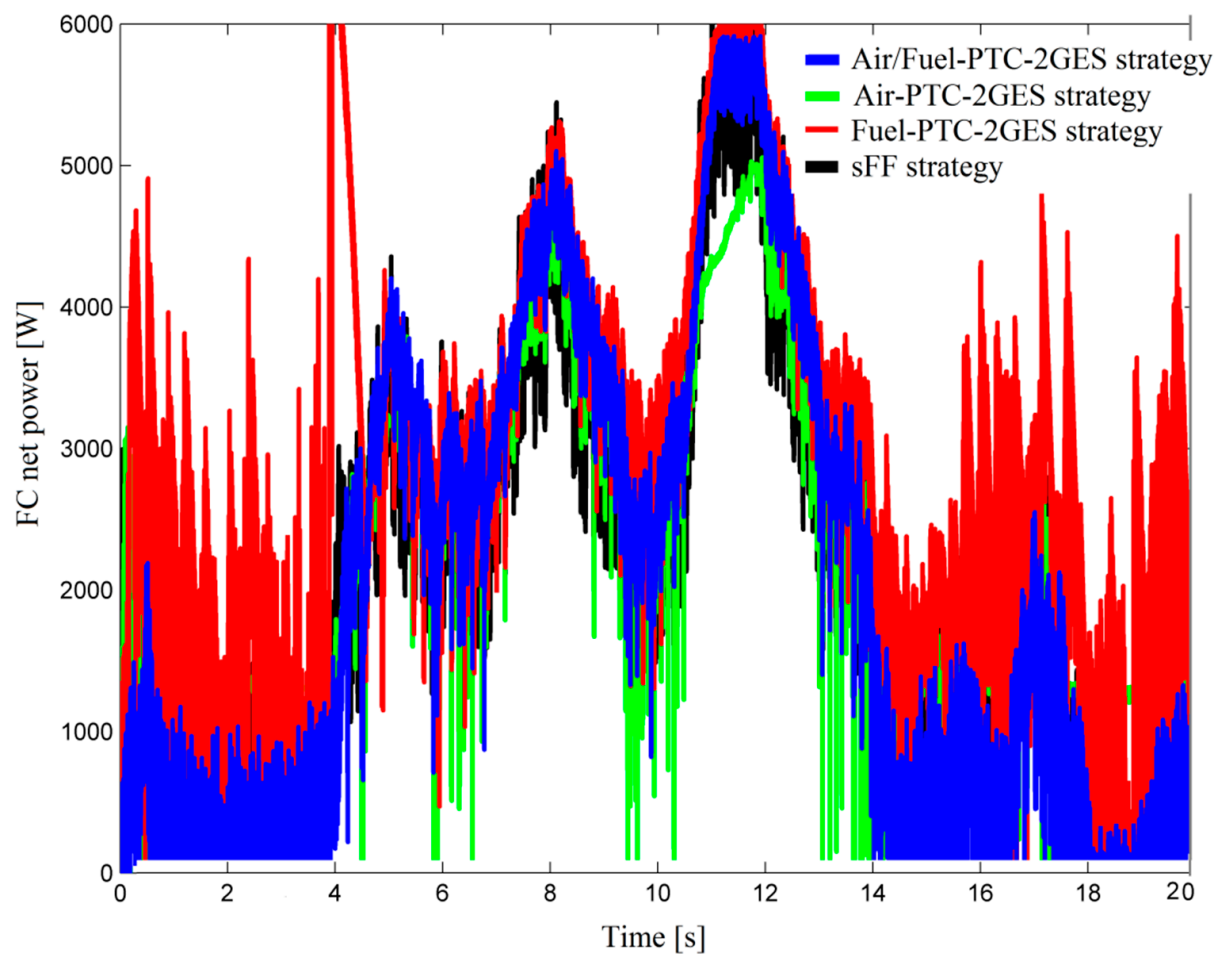

Figure 14. FC net power supplied on the DC bus of RES FC HPS. 


\subsection{Oxygen Excess Ratio}

\subsubsection{FC HPS}

The OER variation is monitored for all strategies and shown in Figure 15.

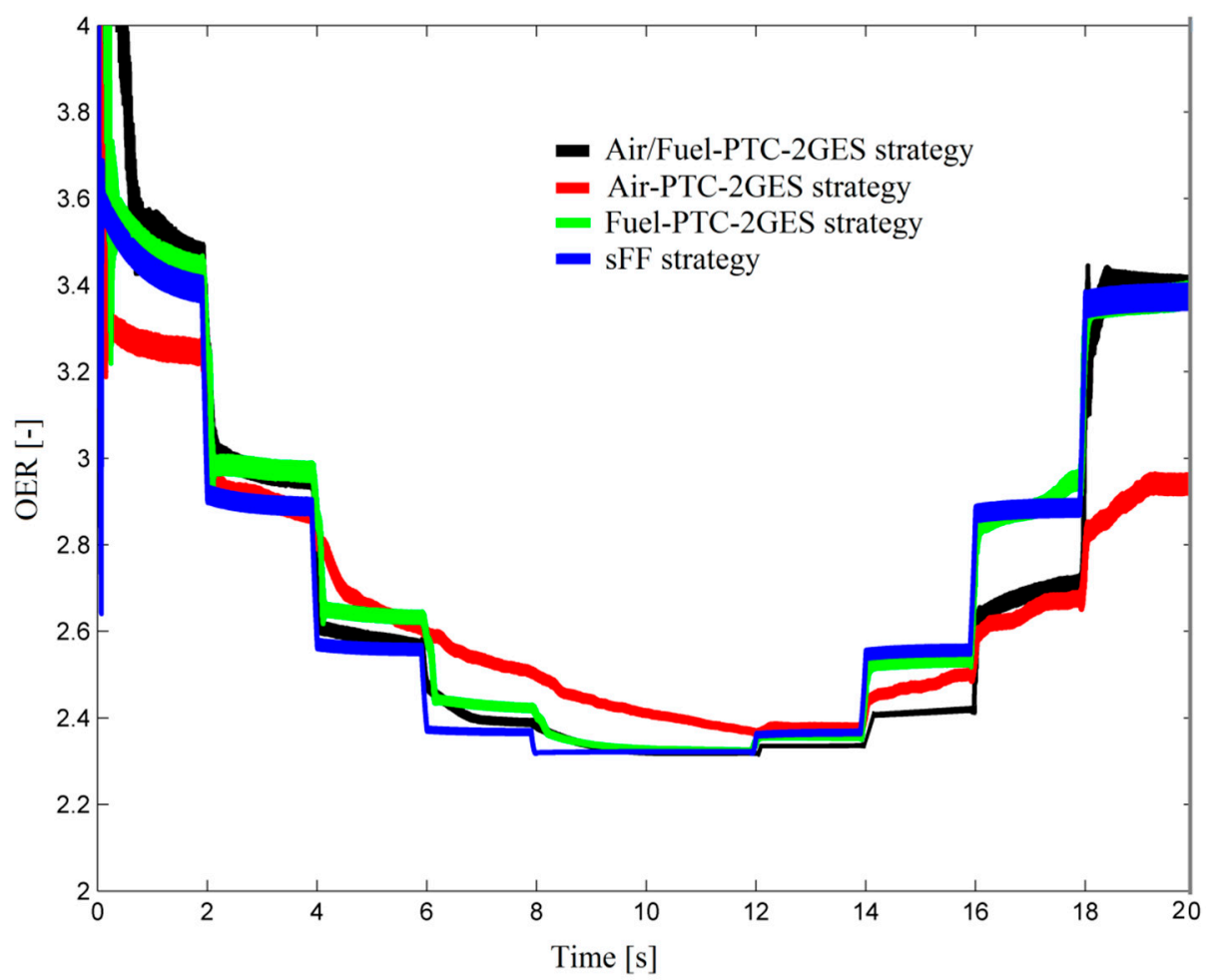

Figure 15. Oxygen excess ratio for FC HPS.

Note that the OER range is within the safe limits of FC operation, from about 2.3 to 3.6 for any load demand profile $[36,75,76]$. The excess oxygen ratio (OER) is expressed as the ratio between the oxygen flow consumed in the electrochemical reaction of the stack and the oxygen flow generated by the air compressor at the cathodic input of the stack [69]. The reference value must be OER $\geq 2$ to prevent oxygen starvation [75]. An OER excess leads to an increase in the partial pressure of oxygen, and thus the power performance is improved; however, after the optimal values of pressure and hydration level are reached, further increases of OER cause an increase in the power consumption consumed by the air compressor degrading the electrical efficiency of the system. At lower power densities of the stack, there is a possibility of a flooding effect, with the water formed inside possibly blocking the oxygen flow channels and leading to sudden drops in voltage. This critical problem can be overcome if OER is higher than 2, which is visible in Figure 15. At high power densities of the stack, the flooding effect is overcome through the significant increase of the stack temperature [80]. Figure 15 shows that the oxygen excess ratio follows the load profile in Figure 1. The proposed Air/Fuel-PTC-2GES strategy is the most optimal because the stack responds to changes in levels as flat as possible. For example, Figure 13 shows that at the 6000-7000 W power level, the proposed Air/Fuel-PTC-2GES strategy controls the FC power much easier than the SFF strategy, hence an increase in operational safety, while simultaneously showing a higher net FC power, especially downhill, therefore an increase in electrical efficiency can be obtained. 


\subsubsection{RES FC HPS}

OER range is still within the safe limits of FC operation, from 2.3 to less than 7 for any load demand and renewable power profiles (see Figure 16). The upper value is higher because FC net power supplied on the DC bus starts from about $100 \mathrm{~W}$ and $3900 \mathrm{~W}$ for RES FC HPS (see Figure 14) and FC HPS (see Figure 13), respectively. Analyzing the data from plot 9 (electrical efficiency) in Figures 9-12, it is observed that the Air/Fuel PTC-2GS strategy ensures the highest electrical efficiency. This strategy provides a fast response for regulating reactant gas flows during fast power transitions. Insufficient oxidant supply of the PEMFC and obstruction of the gas channels due to flooding with liquid water are the main causes of cell voltage reversal [57]. During the experiments, the cell voltage reversal can be detected by monitoring the voltages on each cell and by setting an alarm threshold for the monitored voltage so that the algorithm can adjust the operating parameters to avoid reversing the cell voltage. To avoid the repeated PEMFC on/off cycles at low power, known as cycles that have a significant impact on damaging the Pt catalyst and on the protection of the battery from overcharging, the PTC controller adjusts the PEMFC so that it should operate at low power (around $100 \mathrm{~W}$ ). In this situation, the Air/Fuel PTC-2GS strategy is able to ensure a higher OER, which will increase the humidity of the membrane. In the situation where PEMFC operates at high powers, water production ensures the optimum degree of humidification of the electrochemical reaction, and Air/Fuel PTC-2GS strategy ensures a lower OER, having the advantage that the energy consumed by the air compressor is reduced. This behavior described above is visible in Figure 16.

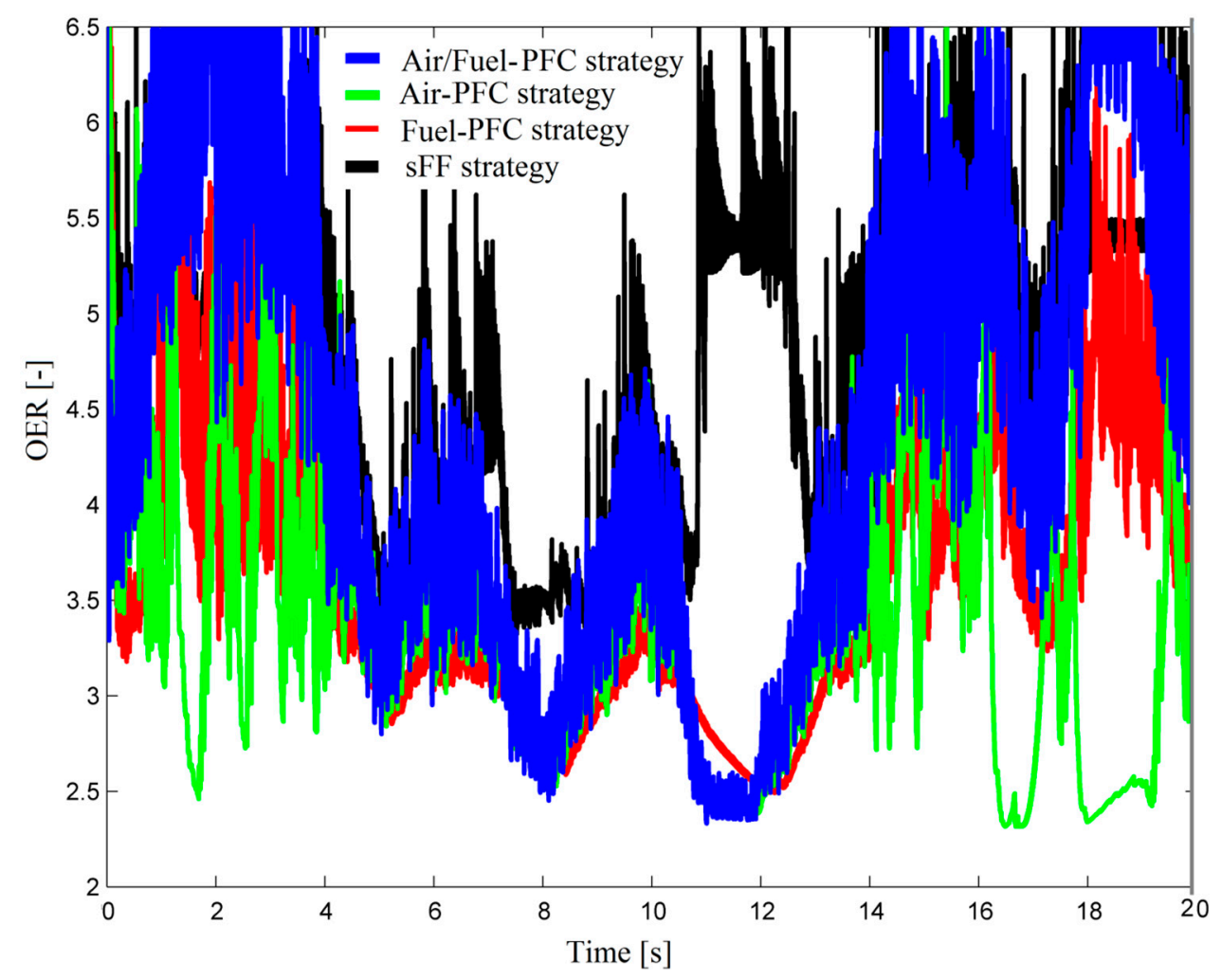

Figure 16. Oxygen excess ratio for RES FC HPS.

\section{Discussion}

The discussion of the results presented in the section above is briefly shown below. The hydrogen consumption for the strategies sFF, Air-PTC-2GES, Fuel-PTC-2GES and Air/Fuel-PTC-2GES is shown in Table 5. 
Table 5. Hydrogen consumption for FC HPS with and without RES power.

\begin{tabular}{|c|c|c|c|c|}
\hline Parameter [unit] & $\begin{array}{c}\text { sFF } \\
\text { Benchmark }\end{array}$ & $\begin{array}{c}\text { Air- } \\
\text { PTC-2GES }\end{array}$ & $\begin{array}{c}\text { Fuel- } \\
\text { PTC-2GES }\end{array}$ & $\begin{array}{l}\text { Air/Fuel- } \\
\text { PTC-2GES }\end{array}$ \\
\hline Fuel $_{T(\text { strategy })}[$ liters] & 286.5 & 267.5 & 274 & 247.2 \\
\hline Fuel $_{T(\text { strategy })}^{\text {RES }}[$ liters] & 123.6 & 114.6 & 117.5 & 105.1 \\
\hline $\mathrm{Fuel}_{T(\text { strategy })}-$ Fuel $_{T(\text { strategy })}^{\text {RES }}[$ liters $]$ & 162.9 & 152.9 & 156.5 & 142.1 \\
\hline$\frac{\text { Fuel }_{T \text { strategy })}^{R E S}}{\text { Fuel }_{T(\text { strategy })}^{\text {Re }}}[-]$ & 43.14 & 42.84 & 42.88 & 42.52 \\
\hline
\end{tabular}

The Minimum hydrogen consumption is obtained using Air/Fuel-PTC-2GES for FC HPS with and without RES power. Table 5 shows that all three proposed strategies exceed the performance of the sFF strategy in terms of minimizing hydrogen consumption. The reason is that the sFF strategy controls the current using a control Load-Following loop, so it regulates the hydrogen flow in relation to the load demand. Compared to the SFF strategy, the strategies proposed in this paper use two search controllers based on the GES scheme, one to regulate the fuel and another to control the fuel cell converter. In addition, compared to the research conducted in [81], where the aim was to maximize the net power of the fuel cell, here both controllers use a mixt optimization function ( $\mathrm{f}(\mathrm{AirFr}, \mathrm{FuelFr})=k_{\text {net }} P_{F C n e t}$ $\left.+k_{f u e l} F_{u e l} l_{e f f}\right)$ to minimize fuel consumption, where the coefficient $k_{\text {net }}$ is optimized in the reference [52]. The fuel economy obtained for all three strategies is higher than the $7.8 \%$ and $6.8 \%$ reported in the references [33,82].

The hydrogen economy compared to the sFF benchmark is computed using (15) and summarized in Table 6 for FC HPS with and without RES power.

Table 6. Hydrogen economy for FC HPS with and without RES power.

\begin{tabular}{|c|c|c|c|}
\hline Parameter [unit] & $\begin{array}{l}\text { Air- } \\
\text { PTC-2GES }\end{array}$ & $\begin{array}{c}\text { Fuel- } \\
\text { PTC-2GES }\end{array}$ & $\begin{array}{l}\text { Air/Fuel- } \\
\text { PTC-2GES }\end{array}$ \\
\hline$\% \mathrm{Fuel}_{T(\text { strategy })}[\%]$ & 6.63 & 4.36 & 13.72 \\
\hline$\%$ Fuel $_{T(\text { stategy })}^{\text {RES }}[\%]$ & 7.28 & 4.94 & 14.97 \\
\hline$\frac{\%{ }^{2} \text { uul }_{T}^{\text {RES }} \text { (stategy) }}{\% \text { Fuel }_{T(\text { stategy })}}[-]$ & 1.10 & 1.13 & 1.09 \\
\hline$\%$ Fuel $_{T(\text { stategy })}^{\text {RES }}-\%$ Fuel $_{T(\text { stategy })}[\%]$ & 0.65 & 0.57 & 1.25 \\
\hline
\end{tabular}

The percentages $\%$ Fuel $_{T(\text { strategy) }}$ and \%Fuel RES $R$ (stategy) for Air/Fuel-PTC-2GES strategy is about double and triple compared to the strategies Air-PTC-2GES, Fuel-PTC-2GES. However, it is worth mentioning

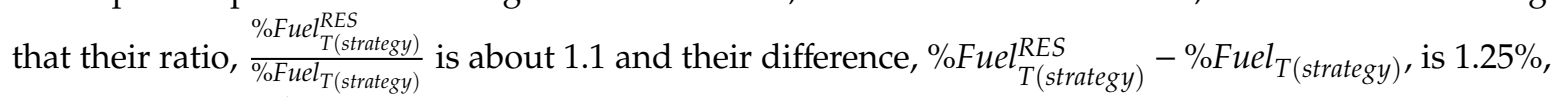
$0.65 \%$ and $0.57 \%$ for strategies Air/Fuel-PTC-2GES, Air-PTC-2GES and Fuel-PTC-2GES, respectively. This showed for all strategies that the hydrogen economy for RES FC HPS compared to FC HPS is almost the same due to about $2.2 \mathrm{~kW}$ RES power supplying the DC bus with about $44 \%(=2.2 \mathrm{~kW} / 5 \mathrm{~kW})$ from $5 \mathrm{KV}$ MV of the load cycle considered in Figure 1. Note that the ratio $\frac{\left.F_{u e l}\right|_{T(\text { strategy) }} ^{\text {Res }}}{\text { Fue }_{T(\text { strategy })}}$ mentioned in the last row of Table 5 is about $43 \%$, being close to the $44 \%$ mentioned above. However, the highest increase in the percentage difference is also obtained for Air/Fuel-PTC-2GES strategy.

Another objective of the control strategy is to control the oxygen excess ratio because the OER value has a great influence on the performance of the fuel cell. The reference value of this ratio corresponding to each strategy was OER $\geq 2$. It is also known that the air compressor is a high energy-consuming device in a fuel cell system so that to increase the electrical efficiency of the whole system, the power consumption of the compressor had to be optimized. It has been shown that the 
proposed strategy for Air/Fuel-PTC-2GES strategy is the most optimal, even if at low fuel cell powers, a higher OER value was obtained; however, this is recommended to avoid membrane dehydration in spite of the disadvantage of BoP consumption. Otherwise, over the entire power range of the load, the control strategy ensures optimal control of the OER value, avoiding oxygen starvation and reducing energy consumption. The simulation results verify the effectiveness of the proposed controller.

During the start/stop cycles, as well as during the long-term operation of the FCS (at the OCV value), especially for RES FC HPS, the catalyst layer at the cathode is significantly affected by the carbon corrosion. In the FC HPS version, this phenomenon does not happen (because no repetitive cycles or OCV occurs). The FCS follows the load profile, and the results are presented in Figure 13. It is easy to see that the net power of FCS for all three strategies is high enough to avoid the operation of FCS at OCV. In order to minimize the detaching of the carbon support or the agglomeration of platinum metal particles from the catalyst, in the RES FC HPS variant, the electrochemical reaction to/from the active sites of the catalyst must be improved, for example, by increasing of the membrane humidity, which can be obtained especially by using more airflow. The Air/Fuel-PTC-2GES strategy for the RES variant avoids the repetitive cycles and OCV if a minimum power of minimum $100 \mathrm{~W}$ is established; in this case, the excess power can be transformed into hydrogen by using an electrolyzer. (Figure 14). The Air/Fuel-PTC-2GES strategy (shown in Figure 16) can avoid membrane dehydration by adjusting the OER to high values to the detriment of the electrical efficiency of the system.

The battery stack is used in the short term as a power buffer. Thus, the capacity and size of the battery are low compared to other hybrid power sources $[6,35]$. The battery stack operates in the charge-sustaining mode for RES FC HPS and FC HPS, controlled by the FC system's power-tracking control (PTC). In this way, the battery stack is protected from deep discharges or frequent charge-discharge cycles at large and dynamic variations in charging demand. All PTC-2GES algorithms are designed to track the load throughout the operating cycle, where the state-of-charge (SoC) of the battery is almost constant, so the lifetime of the batteries is certainly increased. RES FC HPS mode is more unpredictable due to the RES power variation so that a surplus of power is converted into hydrogen gas by a water electrolyzer, avoiding overcharging the battery.

\section{Conclusions}

In this paper, the optimal and safe operation of the RES FC HPS was analyzed. An extended and systematic analysis of the strategies sFF, Air-PTC-2GES, Fuel-PTC-2GES and Air/Fuel-PTC-2GES is performed in this paper. The strategies were analyzed from the point of view of consumed hydrogen by an FC HPS without and with power from renewable energy sources (RES). The static feed-forward (sFF) control was used as a benchmark strategy under the same dynamic profiles of the load demand and renewable power. The optimization loops use two global extremum seeking (GES) schemes operating at different frequencies to maximize the multimodal optimization function that combines the performance indicators. The analysis of the proposed strategies indicated that the best performance was obtained for the Air/Fuel-PTC-2GES strategy due to the switched mode used for the air and fuel regulators of the FC system, which maximize the fuel economy through the efficient functioning of the FC system under the strategy Air-PTC-2GES or Fuel-PTC-2GES depending on the power requested on the DC bus to balance the power flow. The fuel savings compared to the fuel consumed using the static feed-forward (sFF) control was calculated. The main results of this study can be summed up as follows: $6.63 \%, 4.36 \%$ and $13.72 \%$, respectively, under dynamic load but without RES power. With RES power, the needed FC power on the DC bus is lower, so the FC system operates more efficiently. These percentages were calculated at $7.28 \%, 4.94 \%$ and $14.97 \%$. However, prior to its implementation, the performance of the Air/Fuel-PTC-2GES strategy must be further tested under various load cycles and renewable energy profiles. 
Author Contributions: Conceptualization, methodology and writing—original draft preparation: N.B., M.R.; validation and Supervision: E.K. (Emmanuel Koudoumas), E.C.; formal analysis: N.B., E.C., A.M.; writing-review and editing: N.B., E.K. (Emmanuel Karapidakis). All authors have read and agreed to the published version of the manuscript.

Funding: This research received no external funding.

Acknowledgments: This work was carried out through the Nucleus Program, financed by the Ministry of Education and Research, project no. PN 19110202 "Innovative solution for testing and validating fuel cell systems in automotive applications" and project number PN-III-P1-1.2-PCCDI-2017-0194/25 PCCDI within PNCDI III.

Conflicts of Interest: The authors declare no conflict of interest.

\section{Nomenclature}

Abbreviations:

Air-PTC-2GES

Air/Fuel-PTC-2GES

AV

EMS

EMU

ES

ESS

GES

Fuel-PTC-2GES

FC

FCHPS

HPS

LPM

LFW

MEA

MEP

MPP

MV

PEMFC

PTC

OCV

OER

RES

RTO

sFF

SoC

SW

UC

Abbreviations:

Air-PTC-2GES

Air/Fuel-PTC-2GES

AV

EMS

EMU

ES

ESS

GES

Fuel-PTC-2GES

FC

FCHPS

HPS

LPM
Strategy based on the control of the air regulator

Strategy based on the control of the air regulator and the fuel regulator

Average value

Energy management strategy

Energy management unit

Extremum seeking

Energy storage system

Global extremum seeking

Strategy based on the control of the fuel regulator

Fuel cell

Fuel cell hybrid power systems

Hybrid power system

Liter per minute

Load-following

Membrane electrode assembly

Maximum efficiency point

Maximum power point

Mean value

proton exchange membrane fuel cell

Power-tracking control

Open circuit voltage

Oxygen excess ratio

Renewable energies source

Real-time optimization

Static feed-forward

State-of-charge

Switch

Ultracapacitor

Strategy based on the control of the air regulator

Strategy based on the control of the air regulator and the fuel regulator

Average value

Energy management strategy

Energy management unit

Extremum seeking

Energy storage system

Global extremum seeking

Strategy based on the control of the fuel regulator

Fuel cell

Fuel cell hybrid power systems

Hybrid power system

Liter per minute 


\begin{tabular}{|c|c|}
\hline LFW & Load-following \\
\hline MEA & Membrane electrode assembly \\
\hline MEP & Maximum efficiency point \\
\hline MPP & Maximum power point \\
\hline MV & Mean value \\
\hline PEMFC & proton exchange membrane fuel cell \\
\hline PTC & Power-tracking control \\
\hline $\mathrm{OCV}$ & Open circuit voltage \\
\hline OER & Oxygen excess ratio \\
\hline RES & Renewable energies source \\
\hline RTO & Real-time optimization \\
\hline $\mathrm{sFF}$ & Static feed-forward \\
\hline SoC & State-of-charge \\
\hline SW & Switch \\
\hline $\mathrm{UC}$ & Ultracapacitor \\
\hline \multicolumn{2}{|l|}{ Symbols: } \\
\hline AirFr & Airflow rate \\
\hline$C_{D C}$ & Capacitor DC \\
\hline$f_{d}$ & Dither frequency \\
\hline$F$ & Faraday constant \\
\hline Fuel $_{\text {eff }}$ & Fuel consumption efficiency \\
\hline Fuel Fr $_{F r}$ & Fuel flow rate \\
\hline $\mathrm{Fuel}_{T}$ & Total fuel consumption \\
\hline$k_{\text {fuel }}$ & Weighting coefficient of the fuel consumption efficiency \\
\hline$k_{\text {net }}$ & Weighting coefficient of the FC net power \\
\hline$k_{N y}$ & Normalization gain \\
\hline$k_{R E S}$ & Constant for RES \\
\hline$I_{c m}$ & Air compressor current \\
\hline$I_{F C}$ & FC stack current \\
\hline$I_{\text {ref(Air) }}$ & Air flow reference \\
\hline$I_{\text {ref(Boost })}$ & Boost converter reference \\
\hline$I_{\text {ref(Fuel })}$ & Fuel flow reference \\
\hline$I_{\text {ref(GES1) }}$ & GES 1 references \\
\hline$I_{\text {ref(GES2) }}$ & GES 2 references \\
\hline$I_{r e f(P T C)}$ & PTC references \\
\hline$N_{c}$ & Number of cells in series \\
\hline$P_{f(H 2)}$ & Pressure of the fuel \\
\hline$P_{f(\mathrm{O} 2)}$ & Pressure of the air \\
\hline$P_{D C r e q}$ & Power requested on the DC bus \\
\hline$P_{F C}$ & FC stack power \\
\hline$P_{D C}$ & Power on the DC bus \\
\hline$P_{\text {Load }}$ & Variable load power \\
\hline$R$ & Universal gas constant \\
\hline$v_{1}, v_{2}$ & Variable for the reactant flow rate optimum \\
\hline$V_{c m}$ & Air compressor voltage \\
\hline$V_{F C}$ & FC stack voltage \\
\hline$u_{D C}$ & DC bus voltage \\
\hline$U_{f(H 2)}$ & Nominal utilization of hydrogen \\
\hline$U_{f(\mathrm{O} 2)}$ & Nominal utilization of oxygen \\
\hline$y_{B F}$ & First harmonic of the FC power \\
\hline$y_{\mathrm{O} 2}$ & Composition of oxidant \\
\hline$x_{H 2}$ & Composition of fuel \\
\hline$\Theta$ & Operating temperature \\
\hline$\eta_{\text {sys }}$ & FC electrical efficiency \\
\hline$\eta_{\text {boost }}$ & FC boost converter efficiency \\
\hline
\end{tabular}




\section{References}

1. Owusu, P.A.; Asumadu-Sarkodie, S. A review of renewable energy sources, sustainability issues and climate change mitigation. Cogent Eng. 2016, 3, 1167990. [CrossRef]

2. Chen, S.; Kumar, A.; Wong, W.C.; Chiu, M.-S.; Wang, X. Hydrogen value chain and fuel cells within hybrid renewable energy systems: Advanced operation and control strategies. Appl. Energy 2019, 233, 321-337. [CrossRef]

3. Bizon, N.; Oproescu, M.; Raceanu, M. Efficient energy control strategies for a standalone Renewable/Fuel Cell Hybrid Power Source. Energy Convers. Manag. 2015, 90, 93-110. [CrossRef]

4. Abdin, Z.; Zafaranloo, A.; Rafiee, A.; Mérida, W.; Lipiński, W.; Khalilpour, K.R. Hydrogen as an energy vector. Renew. Sustain. Energy Rev. 2020, 120, 109620. [CrossRef]

5. Strielkowski, W. Chapter 4-Renewable energy sources, power markets, and smart grids. In Strielkowski WBT-SI of SG, Editor; Elsevier: Amsterdam, The Netherlands, 2020; pp. 97-151. [CrossRef]

6. Raceanu, M.; Bizon, N.; Marinoiu, A.; Varlam, M. Design and Experimental Investigations of an Energy Storage System in Microgrids; Springer: Cham, Switzerland, 2020. [CrossRef]

7. Carcadea, E.; Varlam, M.; Marinoiu, A.; Raceanu, M.; Ismail, M.S.S.; Ingham, D.B.B. Influence of catalyst structure on PEM fuel cell performance-A numerical investigation. Int. J. Hydrogen Energy 2019, 44, 12829-12841. [CrossRef]

8. Grigoriev, S.A.; Millet, P.; Porembsky, V.I.; Fateev, V.N. Development and preliminary testing of a unitized regenerative fuel cell based on PEM technology. Int. J. Hydrogen Energy 2011, 36, 4164-4168. [CrossRef]

9. Ito, H.; Miyazaki, N.; Ishida, M.; Nakano, A. Efficiency of unitized reversible fuel cell systems. Int. J. Hydrogen Energy 2016, 41, 5803-5815. [CrossRef]

10. Tanrioven, M.; Alam, M.S. Reliability modeling and analysis of stand-alone PEM fuel cell power plants. Renew. Energy 2006, 31, 915-933. [CrossRef]

11. Raceanu, M.; Marinoiu, A.; Culcer, M.; Varlam, M.; Bizon, N. Preventing reactant starvation of a $5 \mathrm{~kW}$ PEM fuel cell stack during sudden load change. In Proceedings of the 2014 6th International Conference on Electronics, Computers and Artificial Intelligence (ECAI), Bucharest, Romania, 23-25 October 2014; pp. 55-60. [CrossRef]

12. Chen, H.; Zhao, X.; Zhang, T.; Pei, P. The reactant starvation of the proton exchange membrane fuel cells for vehicular applications: A review. Energy Convers. Manag. 2019, 182, 282-298. [CrossRef]

13. Ijaodola, O.S.; El- Hassan, Z.; Ogungbemi, E.; Khatib, F.N.; Wilberforce, T.; Thompson, J.; Olabi, A.G. Energy efficiency improvements by investigating the water flooding management on proton exchange membrane fuel cell (PEMFC). Energy 2019, 179, 246-267. [CrossRef]

14. Bandlamudi, V.; Bujlo, P.; Sita, C.; Pasupathi, S. Study on electrode carbon corrosion of high temperature proton exchange membrane fuel cell. Mater. Today Proc. 2018, 5, 10602-10610. [CrossRef]

15. Schonvogel, D.; Hülstede, J.; Wagner, P.; Dyck, A.; Agert, C.; Wark, M. Durability of Electrocatalysts for ORR: Pt on Nanocomposite of Reduced Graphene Oxide with FTO versus Pt/C. J. Electrochem. Soc. 2018, 165, F3373. [CrossRef]

16. Lochner, T.; Hallitzky, L.; Perchthaler, M.; Obermaier, M.; Sabawa, J.; Enz, S.; Bandarenka, A.S. Local degradation effects in automotive size membrane electrode assemblies under realistic operating conditions. Appl. Energy 2020, 260, 114291. [CrossRef]

17. Wang, G.; Huang, F.; Yu, Y.; Wen, S.; Tu, Z. Degradation behavior of a proton exchange membrane fuel cell stack under dynamic cycles between idling and rated condition. Int. J. Hydrogen Energy 2018, 43, 4471-4481. [CrossRef]

18. Panha, K.; Fowler, M.; Yuan, X.-Z.; Wang, H. Accelerated durability testing via reactants relative humidity cycling on PEM fuel cells. Appl. Energy 2012, 93, 90-97. [CrossRef]

19. Pei, P.; Chang, Q.; Tang, T. A quick evaluating method for automotive fuel cell lifetime. Int. J. Hydrogen Energy 2008, 33, 3829-3836. [CrossRef]

20. Barbir, F. Chapter Ten-Fuel Cell Applications. In Barbir FBT-PEMFC, 2nd ed.; Academic Press: Boston, MA, USA, 2013; pp. 373-434. [CrossRef]

21. Wang, J. System integration, durability and reliability of fuel cells: Challenges and solutions. Appl. Energy 2017, 189, 460-479. [CrossRef]

22. Wu, D.; Peng, C.; Yin, C.; Tang, H. Review of System Integration and Control of Proton Exchange Membrane Fuel Cells. Electrochem. Energy Rev. 2020, 3, 466-505. [CrossRef] 
23. Wang, Y.; Ruiz Diaz, D.F.; Chen, K.S.; Wang, Z.; Adroher, X.C. Materials, technological status, and fundamentals of PEM fuel cells-A review. Mater. Today 2020, 32, 178-203. [CrossRef]

24. Lai, Y.H.; Fly, G.W. In-situ diagnostics and degradation mapping of a mixed-mode accelerated stress test for proton exchange membranes. J. Power Source 2015, 274, 1162-1172. [CrossRef]

25. Marinoiu, A.; Andrulevicius, M.; Tamuleviciene, A.; Tamulevicius, T.; Carcadea, E.; Raceanu, M.; Varlam, M. High performance catalytic system with enhanced durability in PEM fuel cell. Int. J. Hydrogen Energy 2020, 45, 10409-10422. [CrossRef]

26. Marinoiu, A.; Andrulevicius, M.; Tamuleviciene, A.; Tamulevicius, T.; Raceanu, M.; Varlam, M. Synthesis of well dispersed gold nanoparticles on reduced graphene oxide and application in PEM fuel cells. Appl. Surf. Sci. 2020, 504, 144511. [CrossRef]

27. Marinoiu, A.; Gatto, I.; Raceanu, M.; Varlam, M.; Moise, C.; Pantazi, A.; Jianu, C.; Stefanescu, I.; Enachescu, M. Low cost iodine doped graphene for fuel cell electrodes. Int. J. Hydrogen Energy 2017, 42, 26877-26888. [CrossRef]

28. Marinoiu, A.; Raceanu, M.; Andrulevicius, M.; Tamuleviciene, A.; Tamulevicius, T.; Nica, S.; Bala, D.; Varlam, M. Low-cost preparation method of well dispersed gold nanoparticles on reduced graphene oxide and electrocatalytic stability in PEM fuel cell. Arab. J. Chem. 2019, 13, 3585-3600. [CrossRef]

29. Marinoiu, A.; Raceanu, M.; Carcadea, E.; Varlam, M. Iodine-doped graphene-Catalyst layer in PEM fuel cells. Appl. Surf. Sci. 2018, 456, 238-245. [CrossRef]

30. Marinoiu, A.; Raceanu, M.; Carcadea, E.; Varlam, M.; Stefanescu, I. Low cost iodine intercalated graphene for fuel cells electrodes. Appl. Surf. Sci. 2017, 424, 93-100. [CrossRef]

31. Dyantyi, N.; Parsons, A.; Bujlo, P.; Pasupathi, S. Behavioural study of PEMFC during start-up/shutdown cycling for aeronautic applications. Mater. Renew. Sustain. Energy 2019, 8, 4. [CrossRef]

32. Zhang, T.; Wang, P.; Chen, H.; Pei, P. A review of automotive proton exchange membrane fuel cell degradation under start-stop operating condition. Appl. Energy 2018, 223, 249-262. [CrossRef]

33. Han, X.; Li, F.; Zhang, T.T.; Zhang, T.T.; Song, K. Economic energy management strategy design and simulation for a dual-stack fuel cell electric vehicle. Int. J. Hydrogen Energy 2017, 42, 11584-11595. [CrossRef]

34. Aschilean, I.; Varlam, M.; Culcer, M.; Iliescu, M.; Raceanu, M.; Enache, A.; Raboaca, M.S.; Rasoi, G.; Filote, C. Hybrid electric powertrain with fuel cells for a series vehicle. Energies 2018, 11, 1294. [CrossRef]

35. Bizon, N.; Raceanu, M. Energy Efficiency of PEM Fuel Cell Hybrid Power Source. In Energy Harvesting and Energy Efficiency; Bizon, N., Mahdavi Tabatabaei, N., Blaabjerg, F., Kurt, E., Eds.; Springer International Publishing: Cham, Switzerland, 2017; Volume 37, pp. 371-391. [CrossRef]

36. Guo, A.; Chen, W.; Li, Q.; Liu, Z.; Que, H. Air flow control based on optimal oxygen excess ratio in fuel cells for vehicles. J. Mod. Transp. 2013, 21, 79-85. [CrossRef]

37. Rojas, A.C.; Lopez, G.L.; Gomez-Aguilar, J.F.; Alvarado, V.M.; Torres, C.L.S. Control of the air supply subsystem in a PEMFC with balance of plant simulation. Sustainability 2017, 9, 73. [CrossRef]

38. Bona, D.; Curtin, D.E.; Pedrazzo, F.; Tresso, E.M. Using a Stack Shunt to Mitigate Catalyst Support Carbon Corrosion in Polymer Electrolyte Membrane Fuel Cell Stacks during Start-Stop Cycling. J. Fuel Cell Sci. Technol. 2014, 11, 011010. [CrossRef]

39. Macauley, N.; Papadias, D.D.; Fairweather, J.; Spernjak, D.; Langlois, D.; Ahluwalia, R.; More, K.L.; Mukundan, R.; Borup, R.L. Carbon Corrosion in PEM Fuel Cells and the Development of Accelerated Stress Tests. J. Electrochem. Soc. 2018, 165, F3148. [CrossRef]

40. Daud, W.R.W.; Rosli, R.E.; Majlan, E.H.; Hamid, S.A.A.; Mohamed, R.; Husaini, T. PEM fuel cell system control: A review. Renew. Energy 2017, 113, 620-638. [CrossRef]

41. Dale, N. Durability Evaluation of PEM Fuel Cells for Automotive Application. ECS Meet. Abstr. 2017, 33, 104094. [CrossRef]

42. Chen, H.; Song, Z.; Zhao, X.; Zhang, T.; Pei, P.; Liang, C. A review of durability test protocols of the proton exchange membrane fuel cells for vehicle. Appl. Energy 2018, 224, 289-299. [CrossRef]

43. Bizon, N. Searching of the extreme points on photovoltaic patterns using a new Asymptotic Perturbed Extremum Seeking Control scheme. Energy Convers. Manag. 2017, 144, 286-302. [CrossRef]

44. Basha, C.H.; Rani, C. Different conventional and soft computing MPPT techniques for solar PV systems with high step-up boost converters: A comprehensive analysis. Energies 2020, 13, 371. [CrossRef]

45. Kamel, A.A.; Rezk, H.; Shehata, N.; Thomas, J. Energy Management of a DC Microgrid Composed of Photovoltaic/Fuel Cell/Battery/Supercapacitor Systems. Batteries 2019, 5, 63. [CrossRef] 
46. Luta, D.N.; Raji, A.K. Fuzzy rule-based and particle swarm optimisation MPPT techniques for a fuel cell stack. Energies 2019, 12, 936. [CrossRef]

47. Sukumar, S.; Marsadek, M.; Ramasamy, A.; Mokhlis, H.; Mekhilef, S. A fuzzy-based PI controller for power management of a grid-connected PV-SOFC hybrid system. Energies 2017, 10, 1720. [CrossRef]

48. Derbeli, M.; Barambones, O.; Sbita, L. A robust maximum power point tracking control method for a PEM fuel cell power system. Appl. Sci. 2018, 8, 2449. [CrossRef]

49. Derbeli, M.; Charaabi, A.; Barambones, O.; Sbita, L. Optimal Energy Control of a PEM Fuel Cell/Battery Storage System. In Proceedings of the 2019 10th International Renewable Energy Congress, Sousse, Tunisia, 26-28 March 2019; pp. 1-5. [CrossRef]

50. Garcia-Gabin, W.; Dorado, F.; Bordons, C. Real-time implementation of a sliding mode controller for air supply on a PEM fuel cell. J. Process Control 2010, 20, 325-336. [CrossRef]

51. Amirkhan, S.; Radmehr, M.; Rezanejad, M.; Khormali, S. A robust control technique for stable operation of a DC/AC hybrid microgrid under parameters and loads variations. Int. J. Electr. Power Energy Syst. 2020, 117, 105659. [CrossRef]

52. Bizon, N. Efficient fuel economy strategies for the Fuel Cell Hybrid Power Systems under variable renewable/load power profile. Appl. Energy 2019, 251, 113400. [CrossRef]

53. Bizon, N.; Mazare, A.G.; Laurentiu, I.M.; Oproescu, M.; Lopez-Guede, J.M.; Varlam, M.; Raceanu, M.; Cristian, H.I. Renewable (REW)/Fuel Cell (FC) Hybrid Power System with mitigation of the REW variability by the FC fuel flow control. In Proceedings of the 2018 10th International Conference on Electronics, Computers and Artificial Intelligence (ECAI), Iasi, Romania, 28-30 June 2018. [CrossRef]

54. Bizon, N. Real-time optimization strategies of Fuel Cell Hybrid Power Systems based on Load-following control: A new strategy, and a comparative study of topologies and fuel economy obtained. Appl. Energy 2019, 241, 444-460. [CrossRef]

55. Bizon, N.; Thounthong, P. Energy efficiency and fuel economy of a fuel cell/renewable energy sources hybrid power system with the load-following control of the fueling regulators. Mathematics 2020, 8, 151. [CrossRef]

56. Farmann, A.; Waag, W.; Marongiu, A.; Sauer, D.U. Critical review of on-board capacity estimation techniques for lithium-ion batteries in electric and hybrid electric vehicles. J. Power Source 2015, 281, 114-130. [CrossRef]

57. Schaltz, E.; Khaligh, A.; Rasmussen, P.O.; Sheng, Z.H.; Shao, L.; Chen, J.J. Investigation of battery/ultracapacitor energy storage rating for a Fuel Cell Hybrid Electric Vehicle. In Proceedings of the 2008 IEEE Vehicle Power and Propulsion Conference, Harbin, China, 3-5 September 2008; Volume 5, pp. 5-10. [CrossRef]

58. Iliescu, M.; Raceanu, M.; Culcer, M.; Enache, A.; Varlam, M. Fuel Cell based Powertrain Simulations to Find the Power Splitting Leading to Improved Characteristics. Prog. Cryog. Isot. Sep. 2017, 20, 63.

59. Gualous, H.; Louahlia-Gualous, H.; Gallay, R.; Miraoui, A. Supercapacitor Thermal Modeling and Characterization in Transient State for Industrial Applications. IEEE Trans. Ind. Appl. 2009, 45, 1035-1044. [CrossRef]

60. Brady, J.; O'Mahony, M. Development of a driving cycle to evaluate the energy economy of electric vehicles in urban areas. Appl. Energy 2016, 177, 165-178. [CrossRef]

61. Sun, Z.; Wen, Z.; Zhao, X.; Yang, Y.; Li, S. Real-World Driving Cycles Adaptability of Electric Vehicles. World Electr. Veh. J. 2020, 11, 19. [CrossRef]

62. Qin, C.; Wang, J.; Yang, D.; Li, B.; Zhang, C. Proton exchange membrane fuel cell reversal: A review. Catalysts 2016, 6, 197. [CrossRef]

63. Wilberforce, T.; Alaswad, A.; Palumbo, A.; Dassisti, M. Advances in stationary and portable fuel cell applications. Int. J. Hydrogen Energy 2016, 41, 16509-16522. [CrossRef]

64. Chen, Y.S.; Lin, S.M.; Hong, B.S. Experimental study on a passive fuel Cell/Battery hybrid power system. Energies 2013, 6, 6413-6422. [CrossRef]

65. Zhang, J.; Xu, S.; Din, Z.; Hu, X. Hybrid multilevel converters: Topologies, evolutions and verifications. Energies 2019, 12, 615. [CrossRef]

66. Chandrasekar, B.; Nallaperumal, C.; Dash, S.S. A nonisolated three-port DC-DC converter with continuous input and output currents based on Cuk topology for PV/fuel cell applications. Electronics 2019, 8, 214. [CrossRef]

67. Mahadik, Y.; Vadirajacharya, K. Battery life enhancement in a hybrid electrical energy storage system using a multi-source inverter. World Electr. Veh. J. 2019, 10, 17. [CrossRef]

68. Sorrentino, M.; Cirillo, V.; Nappi, L. Development of flexible procedures for co-optimizing design and control of fuel cell hybrid vehicles. Energy Convers. Manag. 2019, 185, 537-551. [CrossRef] 
69. Pan, Z.F.; An, L.; Wen, C.Y. Recent advances in fuel cells based propulsion systems for unmanned aerial vehicles. Appl. Energy 2019, 240, 473-485. [CrossRef]

70. Ramos-Paja, C.A.; Spagnuolo, G.; Petrone, G.; Mamarelis, E. A perturbation strategy for fuel consumption minimization in polymer electrolyte membrane fuel cells: Analysis, Design and FPGA implementation. Appl. Energy 2014, 119, 21-32. [CrossRef]

71. Bizon, N. Fuel saving strategy using real-time switching of the fueling regulators in the proton exchange membrane fuel cell system. Appl. Energy 2019, 252, 113449. [CrossRef]

72. Pukrushpan, J.T.; Stefanopoulou, A.G.; Peng, H. Control of Fuel Cell Power Systems; Springer: New York, NY, USA, 2004.

73. SimPowerSystems, T.M. Reference. Hydro-Québec and the MathWorks; The MathWorks, Inc.: Natick, MA, USA, 2010.

74. Pukrushpan, J.T.; Stefanopoulou, A.G.; Peng, H. Control of fuel cell breathing. IEEE Control Syst. Mag. 2004, 24, 30-46. [CrossRef]

75. Kunusch, C.; Puleston, P.F.; Mayosky, M.A.; Riera, J. Sliding Mode Strategy for PEM Fuel Cells Stacks Breathing Control Using a Super-Twisting Algorithm. IEEE Trans. Control Syst. Technol. 2009, 17, 167-174. [CrossRef]

76. Bizon, N. Sensitivity analysis of the fuel economy strategy based on load-following control of the fuel cell hybrid power system. Energy Convers. Manag. 2019, 199, 111946. [CrossRef]

77. Thounthong, P.; Raducu, M.; Constantinescu, L.M. Designing and modelling of the asymptotic perturbed extremum seeking control scheme for tracking the global extreme. Int. J. Hydrogen Energy 2017, 42, 17632-17644. [CrossRef]

78. Bizon, N.; Kurt, E. Performance analysis of the tracking of the global extreme on multimodal patterns using the Asymptotic Perturbed Extremum Seeking Control scheme. Int. J. Hydrogen Energy 2017, 42, 17645-17654. [CrossRef]

79. Restrepo, C.; Ramos-Paja, C.A.; Giral, R.; Calvente, J.; Romero, A. Fuel cell emulator for oxygen excess ratio estimation on power electronics applications. Comput. Electr. Eng. 2012, 38, 926-937. [CrossRef]

80. Park, J.; Li, X. Effect of flow and temperature distribution on the performance of a PEM fuel cell stack. J. Power Source 2006, 162, 444-459. [CrossRef]

81. Hoarca, C.I.; Enescu, F.M. On the energy efficiency of standalone fuel cell/renewable hybrid power sources Part I: Simulation results for constant load profile without RES power. In Proceedings of the 2018 International Conference on Applied and Theoretical Electricity (ICATE), Craiova, Romania, 4-6 October 2018; pp. 2-6. [CrossRef]

82. Shin, D.; Lee, K.; Chang, N. Fuel economy analysis of fuel cell and supercapacitor hybrid systems. Int. J. Hydrogen Energy 2016, 41, 1381-1390. [CrossRef]

Publisher's Note: MDPI stays neutral with regard to jurisdictional claims in published maps and institutional affiliations.

(C) 2020 by the authors. Licensee MDPI, Basel, Switzerland. This article is an open access article distributed under the terms and conditions of the Creative Commons Attribution (CC BY) license (http://creativecommons.org/licenses/by/4.0/). 